\title{
The Plio-Pleistocene record of Hypolagus (Lagomorpha, Leporidae) from the Czech and Slovak Republics with comments on systematics and classification of the genus
}

\author{
STANISLAV ČERMÁK
}

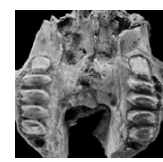

\begin{abstract}
A proven record of Hypolagus (Lagomorpha, Mammalia) from twenty-two Plio-Pleistocene (Ruscinian-Biharian) localities of the Czech and Slovak Republics is presented; from eight localities the genus is reported or described for the first time. A detailed description and morphological analysis of the currently available dental and cranial material proved the presence of two species in the studied area and enabled to assessment of their intra- and interspecific variability, as well as the phylogenetic level of some paleopopulations. The complete history of research on the Central European Hypolagus is summarized, accompanied by nomenclatural revision and synonymy. A revision and designation of the type material is provided. The results are expressed in a description of Hypolagus petenyii Čermák \& Fladerer sp. nov. from the Pliocene (Early Villányian) locality of Beremend (Hungary). In the studied area: (1) the gracile and less advanced $H$. petenyii Čermák \& Fladerer sp. nov., characterized by a simple P2 and p3, is recorded from the Pliocene (Late Ruscinian-Early Villányian) localities of Měňany 3, Ivanovce 1, Hajnáčka I and Hostovce 2; (2) H. brachygnathus (Kormos, 1930), the larger and more robust species with a greater variability of more advanced P2 and p3, persisted throughout the Early Pleistocene (Biharian), with its last appearance in the Late Biharian locality Chlum 4. A taxonomical review and/or revision of Central European finds is provided and discussed in the context of phylogeny and systematics of Eurasian Archaeolaginae leporids. - Key words: Leporidae, Hypolagus petenyii Čermák \& Fladerer sp. nov., H. brachygnathus (Kormos, 1930), Ruscinian, Villányian, Biharian, Europe, Czech Republic, Slovakia, nomenclature, taxonomy.
\end{abstract}

ČERMÁK, S. 2009. The Plio-Pleistocene record of Hypolagus (Lagomorpha, Leporidae) from the Czech and Slovak Republics with comments on systematics and classification of the genus. Bulletin of Geosciences 84(3), 497-524 (6 figures, 2 tables). Czech Geological Survey, Prague. ISSN 1214-1119. Manuscript received October 17, 2008; accepted in revised form March 23, 2009; published online August 12, 2009; issued September 11, 2009.

Stanislav Čermák, Academy of Sciences of the Czech Republic, Institute of Geology, Laboratory of Paleobiology and Paleoecology, Rozvojová 269, CZ-165 00 Prague 6 - Lysolaje, Czech Republic, and National Museum (Natural History), Department of Zoology, Václavské nám.68,CZ-115 79 Prague 1, Czech Republic; cermaks@gli.cas.cz.

The extinct archaeolagine leporid genus Hypolagus forms a notable and important component of the Plio-Pleistocene (Ruscinian-Biharian) fossil record of Central Europe. Pioneer works on the Central European taxa were carried out by Hungarian researchers Salamon János Petényi and Tivadar Kormos (Kubinyi 1856; Petényi 1864; Kormos 1914a, b, 1930, 1930 [1931], 1934) based on fossil records of the genus in Southern Hungary. Lucjan Sych was the first to thoroughly study the problems of the actual morphological and taxonomical diversity of the Central European Hypolagus. His extraordinarily detailed monographic work on the Plio-Pleistocene Hypolagus of Poland (Sych 1965) was unequalled for a long time. The greatest progress in taxonomy of European Hypolagus was made by Florian A. Fladerer (1984, 1987, Fladerer \& Reiner 1996, Fladerer \& Fiore 2003). He produced fundamental work establishing an essential framework for morphotype analy- sis of teeth enamel patterns and stratigraphical settings of the particular taxa.

The environmental conditions during the Ruscinian-Biharian period promoted flourishing and radiation of Hypolagus in Europe (Fladerer \& Reiner 1996, Fladerer \& Fiore 2003). The Central European paleopopulations became rather abundant and yielded a large fossil record in numerous fossil localities of Poland (Kowalski 1958a, 1977; Sulimski 1964; Sych 1964, 1965, 1980; Wolsan 1989, 1990; Fladerer \& Reiner 1996; Fostowicz-Frelik 2003, 2007a, b), the Czech Republic (Fejfar 1961a, b, d, 1964a; Musil 1966, 1974; Tobien 1972; Fladerer 1987; Fladerer \& Reiner 1996; Čermák et al. 2007), Slovakia (Fejfar 1961b, d, 1964b; Fladerer 1987; Ložek \& Horáček 1992; Fladerer \& Reiner 1996; Sabol 2004), Austria (Fladerer 1984, 1987; Fladerer \& Reiner 1996), and Hungary (Kormos 1930, 1934; Kretzoi 1956b, 1962; Jánossy 1963, 1986; Fladerer 1987, Fladerer 


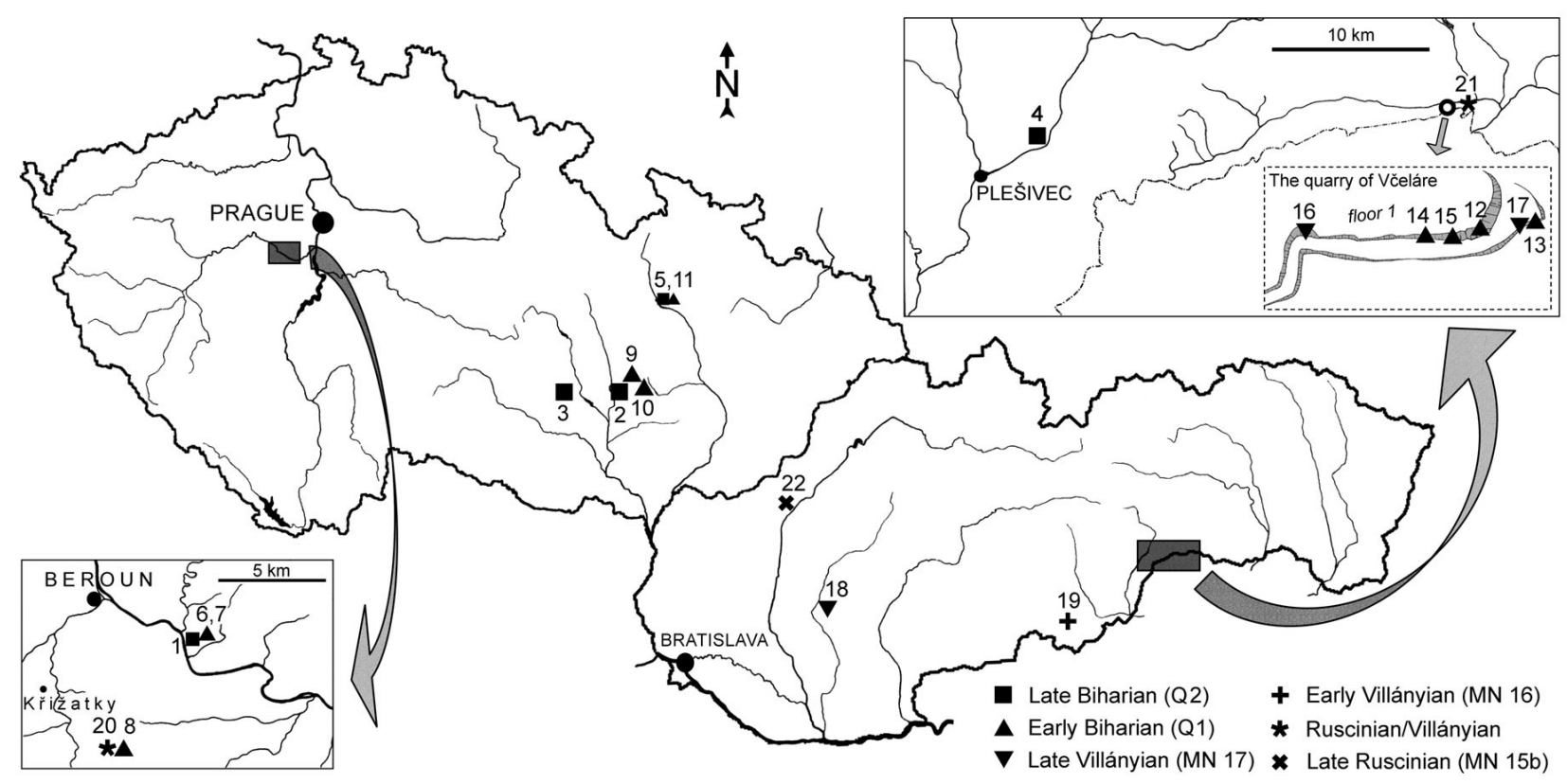

Figure 1. The geographical position of the Plio-Pleistocene (Late Ruscinian-Late Biharian) localities with Hypolagus from the Czech and Slovak Republics (number of localities corresponding to those used in Table 1).

\& Reiner 1996). Perhaps, the most numerous remains assigned to this genus come from the classical Late Ruscinian locality Węże 1 in Poland (Sulimski 1964; Sych 1964, 1965; Fostowicz-Frelik 2007a, b) and the Villányian-Biharian complex of Deutsch-Altenburg in Austria (Fladerer 1984, 1987; Fladerer \& Reiner 1996). From the present viewpoint, the European record includes four species (Gureev 1964, Fladerer 1987, Averianov 1996, Fladerer \& Fiore 2003). In accordance with Fladerer (1987), the Central European species of Hypolagus are commonly referred to as "beremendensis" (the smaller-sized and more primitive form) and brachygnathus (the larger-sized and more cursorial form). Unfortunately, the proper nomenclatoric arrangement of Central European species within Hypolagus received only minor attention except for a few studies (Kretzoi 1962; Fostowicz-Frelik 2003, or 2007a).

The remains of Hypolagus from the Plio-Pleistocene (Ruscinian-Biharian) localities of the Czech and Slovak Republics have not yet been studied in detail. Controversies regarding nomenclature of the Central European taxa in question also persist. This paper fills this gap by providing (1) a detailed morphometric survey of the all currently available dental and cranial material of Hypolagus from localities of the Czech and Slovak Republics, (2) a complete history of research on the Central European Hypolagus, accompanied by a complete nomenclatural revision with synonymy, (3) a revision, designation and description of the type materials of studied taxa, and (4) a discussion and review of their phylogeny, paleobiogeography and possible causes of their extinction.

\section{Material and methods}

The studied leporid material is housed in the collections of CUP, MMB, HMNH and MAFI (see below for explanation of abbreviations). The fossil material from the newly discovered localities Chlum 8 and Měňany 2 and 3 is currently held by the author and will later be deposited in the collections of NMP. For comparative purposes, the morphometric data were partly provided by the author - collections of MAFI, HMNH, NHMK and NHMB; and partly by Kormos (1934); Heller (1936); Schreuder (1937); Kretzoi (1941b); Kowalski (1958a, b); Dehm (1962); Sulimski (1964); Sych (1965, 1966, 1967a, 1980); Berzi (1967); Shushpanov (1977); Fladerer (1987); Popov (1988, 2004); Fladerer \& Reiner (1996); Chaline et al. (2000); Fladerer \& Fiore (2003); Fostowicz-Frelik (2003, 2007a, b); and Maul (2007). The fossil material was processed in a standard way. The new material was recovered from sediment (about $500 \mathrm{~kg}$ from Chlum 8, $600 \mathrm{~kg}$ from Měňany 3 and $20 \mathrm{~kg}$ of pilot sample from Měňany 2) by a conventional screen-washing procedure. All drawings and measurements were taken with the aid of a binocular microscope and ocular micrometer. The dimensions of the teeth were taken on the occlusal surface, from the external borders of the enamel and their maximum length and width were recorded. All measured data are given in millimeters. Abbreviations used in the text and tables are as follows: $\mathrm{N}$ - number of specimens, $\mathrm{M}$ - mean, OR - observed range, SD - standard deviation, L - length, $\mathrm{W}$ - width, FAD/LAD - the first/last appearance datum in the studied area; LL - lingual lobe of P2, BMR - buccal 
Table 1. List of the Czech and Slovak Plio-Pleistocene localities with Hypolagus studied in this paper. Explanatory notes: $\bullet$ A - number of the locality (corresponding to that in the Fig. 1). • B - name of the locality. • C - biostratigraphical correlation (sensu Horáček \& Ložek 1988). D - significance of the micromammalian record (sensu Horáček \& Ložek 1988): 1 - abundant community samples in a continual sequence and/or a very abundant point record (enabling a quantitative treatment), 2 - a sequence in which at least some community samples allow a quantitative approach, or a representative point sample, 3 - a less representative point record. Significance of the record for study of faunal evolution: $\mathrm{a}-$ great, $\mathrm{b}$ - moderate, c - accessory. $\bullet$ E - character of the Hypolagus material under study: N - a new locality with Hypolagus, M - a new (unpublished) or an additional material from the already published locality, D - the first description of the already published (in a faunal list) material, $\mathrm{R}-\mathrm{a}$ revision and more detailed redescription of the already described material. $\bullet \mathrm{F}$ - major references to the localities (in brackets, the character of Hypolagus investigation in the paper: $\mathrm{x}$ - none, $\mathrm{f}$ - mentioned in a faunal list, $\mathrm{d}$ - a description of the material, $\mathrm{t}$ - taxonomic/phylogenetic results, $\mathrm{r}-\mathrm{a}$ part of the revision work).

\begin{tabular}{|c|c|c|c|c|c|}
\hline A & $\mathrm{B}$ & $\mathrm{C}$ & $\mathrm{D}$ & $\mathrm{E}$ & $\mathrm{F}$ \\
\hline 1 & Chlum 4 & Q 2 & 1a & $\mathrm{R}$ & $\begin{array}{l}\text { Fejfar (1964a) (f), Horáček (1979) (x), Fladerer (1987) (r, t), Horáček \& Ložek (1988) (x), Maul (1990) } \\
\text { (f) }\end{array}$ \\
\hline 2 & $\begin{array}{l}\text { Stránská } \\
\text { skála }\end{array}$ & Q 2 & 1a & $\mathrm{R}$ & $\begin{array}{l}\text { Musil (1968) (x), Musil \& Valoch (1968) (f), Tobien (1972) (d), Fladerer (1987) (r, t), Maul (1990) (f), } \\
\text { Fladerer \& Reiner (1996) (r, t), Musil et al. (1995) (f), Musil (2001) (f), Musil \& Valoch (2005) (f) }\end{array}$ \\
\hline 3 & Lažánky 2 & Q 2 & $2 b$ & $\mathrm{R}$ & Musil (1974) (d), Horáček \& Ložek (1988) (x) \\
\hline 4 & Gombasek & Q 2 & $2 \mathrm{a}$ & M & Šuf (1931) (x), Tasnádi-Kubacska \& Soós (1935) (x), Kretzoi [1938 (x), 1941a (x)], Fejfar (1961b) (x) \\
\hline 5 & Mladeč 3 & ?Q 1-Q 2 & $3 \mathrm{c}$ & $\mathrm{R}$ & Horáček \& Ložek [1984 (f), 1988 (f)], Fladerer \& Reiner (1996) (r, t) \\
\hline 6 & Chlum 6 & Q 1 & $2 \mathrm{a}$ & $\mathrm{M} / \mathrm{R}$ & Fejfar [1961a (f), b (f)], Fejfar \& Horáček (1983) (f), Fladerer (1987) (r, t), Fladerer \& Reiner (1996) (r, t) \\
\hline 7 & Chlum 8 & Q 1 & - & $\mathrm{N}$ & under investigation \\
\hline 8 & Měňany 2 & ?Q 1 & - & $\mathrm{N}$ & Žák \& Diedrich (2006) (x); under investigation \\
\hline 9 & Holštejn & Q 1 & $2 \mathrm{a}$ & M & $\begin{array}{l}\text { Musil (1966) (d), Fejfar \& Horáček (1983) (f), Fladerer (1987) (r, t), Maul (1990) (f), Fladerer \& Reiner } \\
\text { (1996) (r, t) }\end{array}$ \\
\hline 10 & Mokrá 1 & Q 1 & $2 \mathrm{a}$ & $\mathrm{R}$ & $\begin{array}{l}\text { Fejfar \& Horáček (1983) (f), Horáček (1984) (x), Fladerer (1987) (r, t), Maul (1990) (f), Fladerer \& } \\
\text { Reiner (1996) (r, t) }\end{array}$ \\
\hline 11 & Mladeč 1 & Q 1 & $2 \mathrm{~b}$ & $\mathrm{R}$ & Horáček \& Ložek [1984 (x), 1988 (x)], Fladerer (1987) (r, t), Fladerer \& Reiner (1996) (r) \\
\hline 12 & Včeláre 4E & Q 1 & 1a & $\mathrm{M} / \mathrm{R}$ & Fejfar \& Horáček (1983) (x), Horáček (1985) (f), Fladerer (1987) (r, t), Fladerer \& Reiner (1996) (r) \\
\hline 13 & Včeláre $6 / 8$ & Q 1 & 1a & $\mathrm{D}$ & Horáček (1985) (f) \\
\hline 14 & Včeláre 10B & Q 1 & $2 \mathrm{~b}$ & $\mathrm{~N} / \mathrm{M}$ & Fejfar \& Horáček (1990) (x) \\
\hline 15 & Včeláre 5 & Q 1 & 1a & $\mathrm{M} / \mathrm{R}$ & Horáček (1985) (f), Fladerer (1987) (r, t), Maul (1990) (f), Fladerer \& Reiner (1996) (r, t) \\
\hline 16 & Včeláre 3/B3 & MN 17 & 1a & $\mathrm{R}$ & Horáček [1980 (f), 1985 (f)], Fladerer (1987) (r, t), Fladerer \& Reiner (1996) (r, t) \\
\hline 17 & Včeláre 7 & MN 17 & $3 \mathrm{~b}$ & $\mathrm{D}$ & Horáček (1985) (f), Fladerer (1987) (r, t), Fladerer \& Reiner (1996) (r) \\
\hline 18 & Koliňany 1 & MN 17 & 1a & $\mathrm{R}$ & Fejfar (1961a) (f), Fejfar \& Horáček (1983), Fladerer (1987) (r, t), Fladerer \& Reiner (1996) (r, t) \\
\hline 19 & Hajnáčka I & MN $16 a$ & $1 \mathrm{a}$ & $\mathrm{R}$ & Fejfar [1961c (f), d (d, t), 1964b (d)], Fladerer (1987) (r, t), Fladerer \& Reiner (1996) (r, t), Sabol (2004) (d, t) \\
\hline 20 & Měňany 3 & MN $15 / 16$ & 1a & N/D & Horáček et al. (2006) (f), Čermák et al. (2007) (f), Čermák et al. (2008) (f); under investigation \\
\hline 21 & Hostovce 2 & MN 15/16 & $2 \mathrm{a}$ & $\mathrm{M} / \mathrm{D}$ & Ložek \& Horáček (1992) (f), Čermák et al. (2008) (f); under investigation \\
\hline 22 & Ivanovce 1 & MN $15 b$ & $1 \mathrm{a}$ & $\mathrm{R}$ & Fejfar [1961b (f), c (f), b (d, t)], Fladerer (1987) (r, t), Fladerer \& Reiner (1996) (r, t) \\
\hline
\end{tabular}

mesial re-entrant angle of $\mathrm{P} 2, \mathrm{MBR}$ - major buccal re-entrant angle of p3 (sensu Fladerer 1987). Capital and lowercase letters, I/i (incisors), $\mathrm{P} / \mathrm{p}$ (premolars), and M/m (molars), refer to upper and lower cheek-teeth, respectively. The dental terminology used here follows Palacios \& LópezMartínez (1980). Dental measurements are taken after Sych (1965) and partly (for comparative purposes) after White (1991). The enamel pattern of p3 and P2 were attributed, with some modifications to the original scheme (see below), into morphological classes proposed by Fladerer (1987) and elaborated by Fladerer \& Reiner (1996). The phylogenetic level of the total sample is quantified using the method of morphodynamic indexes (i.e., frequencies of the classes multiplied by a factor to obtain the morphodynamic index) first introduced by Rabeder (1983) for the Ursus
deningeri-U. spelaeus lineage (see also Rebeder \& Tsoukala 1990) and for the study of Lagomorpha first applied by Fladerer \& Reiner (1996). The morphotypes "d" and "e" of the hypoconid (sensu Fladerer 1987) are merged here into morphotype "d". The hypoconid with antero-buccal crenulation is included here in a new morphotype "e". The modified scheme is shown in Fig. 5A. The biostratigraphic terminology used in this paper follows the terminology by Fejfar \& Heinrich (1983) and/or Horáček \& Ložek (1988). At the time of submission of this paper, the Pliocene/Pleistocene boundary was under discussion (compare with Gradstein et al. 2008 and Ogg \& Pillans 2008), thus it is retained here at ca 1.81 Ma (base of Calabrian). All nomenclatural acts presented here conform to the mandatory provisions of the International Code of Zoological Nomenclature (ICZN 1999). 
Institutional abbreviations. - CUP - Charles University, Department of Zoology, Prague, Czech Republic; HMNH Hungarian Museum of Natural History, Budapest, Hungary; MAFI - Geological Institute of Hungary (Magyar Állami Földtany Intézet), Budapest, Hungary; MMB Moravian Museum, Brno, Czech Republic; NHMB - Natural History Museum, Basel, Switzerland; NHMK - Natural History Museum, Kiev, Ukraine; NMP - National Museum, Prague, Czech Republic; SMF - Senckenberg Museum, Frankfurt am Main, Germany.

\section{Results}

The dental material under study pertaining to the genus Hypolagus exhibits: (1) a short p3 hypoflexid exceeding approximately half of the posteroconid width, (2) a simple p3 anteroconid without well-developed anteroflexid, and (3) P2 with a simple hypercone; i.e., hypoflexus is shallow or absent (cf.e.g., Dice 1929, Dawson 1958, Sych 1965, Fladerer \& Reiner 1996, etc.). Parameters of the occlusal pattern of P2 and p3 (sensu Fladerer 1987, Fladerer \& Reiner 1996, Fladerer \& Fiore 2003) used here to define the phylogenetic level of the dentition and to distinguish the available species are: P2 - (1) morphology of the hypercone together with depth of hypoflexus and (2) morphology of the lagicone together with depth of mesoflexus (LL- and BMR-types, respectively, sensu Fladerer 1987); p3 - (1) morphology of the anteroconid (Trigtypes sensu Fladerer \& Reiner 1996), (2) morphology of the buccal part of the hypoconid (Tal-types sensu Fladerer 1987, slightly modified in this paper), and (3) morphology of the interior part of the hypoflexid (MBR-types sensu Fladerer 1987).

\section{Occurrence}

In the present paper, the genus Hypolagus is reported from twenty two fossil sites in the Czech and Slovak Republics; provided are (a) the first reports or descriptions of Hypolagus material from eight localities (Chlum 8, Měňany 2 and 3 are completely new) and (b) descriptions of new additional Hypolagus material from four localities. The stratigraphical age of the localities spans from the Late Ruscinian (MN 15b) to Late Biharian (Q2). Most of them are cave or fissure fillings situated in the limestone areas of the Bohemian, Moravian, or Slovak Karst. The geographical positions of the Hypolagus-bearing localities are shown in Fig. 1. A list of the localities with brief characteristics, accompanied by major literature sources, is summarized in Table 1. In total, the following items of cranial and dental material belonging to this genus from the above mentioned localities of the Czech and Slovak Republics were:
1) Chlum 4 (CZ): 1 p3 sin (65489/1), 2 P2 dex (65489/2-3); 2) Stránská skála (CZ): 2 p3 dex (SS1950, SS2546); 3) Lažánky 2 (CZ): 1 p3 dex (LZN/1); 4) Gombasek (SK): 1 fragment of dex mandible with i1, p3, p4 (V.24074/5), 1 fragment of dex mandible with p3-p4 (V.24074/6), 4 p3 sin (V.24074/1-4); 5) Mladeč 3 point [7/10] (CZ): 1 p3 $\sin (\mathrm{MLD} 3 / 1)$; 6) Chlum 6 (CZ): 1 fragment of dex mandible with p3-p4 (6553/7), 1 fragment of sin mandible with p3-m2 (6553/10), 1 fragment of sin mandible with p3-m1 (6553/11), 3 p3 sin (6553/2, 6, 9), 8 p3 dex (6553/1, 3-5, 8, I-III fragmentary), 4 P2 $\sin (6553 / 35,36,40,41), 4$ P2 dex (6553/34, 37-39); 7) Chlum 8 (CZ): 1 p3 sin (CH8/4), 4 p3 dex (CH8/1-3, 5); 8) Měňany 2 (CZ): 2 p3 sin (Me2/3, 4 fragmentary), 1 p3 dex (Me2/1), 1 P2 sin (Me2/2); 9) Holštejn (CZ): 2 p3 sin (HOH136, 219), 3 p3 dex (HOH35-36, 137), 1 P2 sin (HOH169); 10) Mokrá 1 (CZ): 1 p3 dex (MOK1/H1/1); 11) Mladeč 1 (CZ): 2 p3 dex (MLD1/1-2), 1 P2 dex (MLD1/3); 12) Včeláre $4 \mathrm{E}(\mathrm{SK}): 1$ fragment of dex mandible with p3-m3 (Vc4E/L1), 1 fragment of dex mandible with $\mathrm{p} 3-\mathrm{m} 2$ (Vc4E/L8), 2 fragments of dex and sin mandible with p3-p4 (Vc4E/L3, 4), 3 p3 sin (Vc4E/L6, 10, 22), 2 p3 dex (Vc4E/L5, 7), 1 P2 dex (Vc4E/L11); 13) Včeláre 6/8 (SK): 1 p3 sin (Vc6/3-1); 14) Včeláre 10B (SK): 3 p3 dex (Vc10B/1-3); 15) Včeláre 5 (SK): 1 p3 sin (Vc5/4), 1 P2 sin (Vc5/6), 3 P2 dex (Vc5/5, 8-9); 16) Včeláre 3/B3 (SK): 1 p3 sin (Vc3/B3/L2), 1 p3 dex (Vc3/B3/L1), 1 P2 dex (Vc3/B3/L3); 17) Včeláre 7 (SK): 1 P2 dex (Vc7/1); 18) Koliňany 1 (SK): 1 p3 $\sin ($ KOL1/1); 19) Hajnáčka I (SK): 2 p3 sin (No. 65401, 2), 1 P2 sin (No.65351); 20) Měňany 3 (CZ): 4 i1 sin (Me3/20-23), 7 i1 dex (Me3/24-30), 3 p3 sin (Me3/3-4, 7), 6 p3 dex (Me3/1, 2, 5, 6, 15, 16), $1 \mathrm{~m} 1$ dex (Me3/31), $1 \mathrm{~m} 2$ sin (Me3/32), $2 \mathrm{~m} 2$ dex (Me3/33), $4 \mathrm{~m} 3$ sin (Me3/34-37), $1 \mathrm{~m} 3$ dex (Me3/38), 32 fragments of lower teeth, 7 I1 sin (Me3/39-45), 7 I1 dex (Me3/46-52), 8 P2 sin (Me3/8-10, 12, 14, 17-19), 3 P2 dex (Me3/11, 13, 73), 2 P3 sin (Me3/53, 54), 5 P4 or M1 sin (Me3/55-59), 1 P4 or M1 dex (Me3/60), 3 M2 sin (Me3/61-63), 9 M2 dex (Me3/64-72), 14 fragments of upper teeth; 21) Hostovce 2 (SK): 1 fragment of dex mandible with i1, p3-m1 (HTE/1), 1 fragment of dex mandible with i1, p4-m1 (HTE/2), 1 fragment of dex mandible with i1, p3-m2 (HTE/3), 1 fragment of dex mandible with p3-m1 (HTE/4), 1 fragment of dex mandible with i1, p3-p4 (HTE/39), 1 fragment of dex mandible with p4-m2 (HTE/51), 3 i1 sin (HTE/44, 45, 57), 5 p3 sin (HTE/8-10, 41, 52), 4 p3 dex (HTE/5-7, 40), 1 hypoconid of p3 sin (HTE/42), 1 p4 sin (HTE/58), $2 \mathrm{~m} 1$ dex (HTE/18, 59), $3 \mathrm{~m} 2$ dex (HTE/19, 46, 47), 10 fragments of lower teeth, 1 fragment of dex maxilla with P3-M1 (HTE/50), 1 maxillar fragment without teeth (HTE/36), 1 I1 $\sin (\mathrm{HTE} / 17), 4$ I1 $\sin (\mathrm{HTE} / 15,16,55,56), 5 \mathrm{P} 2 \sin$ (HTE/11, 12, 14, 43, 54), 2 P2 dex (HTE/13, 53), 1 P3 sin (HTE/48), 1 P3 dex (HTE/60), 4 P4 or M1 sin (HTE/22-25), 1 P4 or M1 dex (HTE/49), 2 M2 sin (HTE/20, 21), 1 M2 dex (HTE/61), 1 M3 dex (HTE/26), 8 fragments of upper teeth; 22) Ivanovce 1 (SK): 1 p3 dex (651314/1), 1 P2 dex (IVN_2).

\section{Descriptions}

The material can be split into two groups:

(Group A) The material obtained from Hajnáčka I, Hostovce 2, Ivanovce 1 and Měnany 3 exhibits the following specificities (Figs 2, 3P-X; Table 2). 

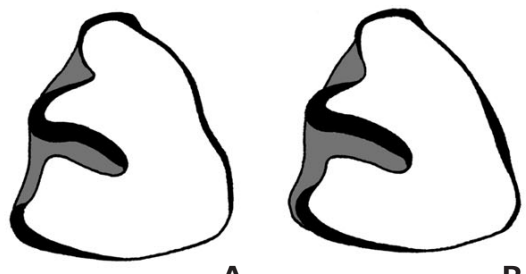

A

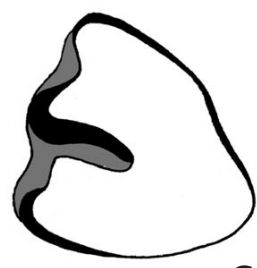

G

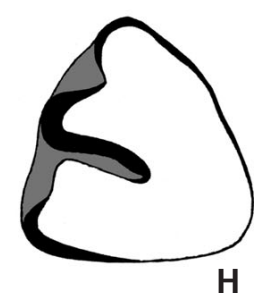

$\mathrm{H}$
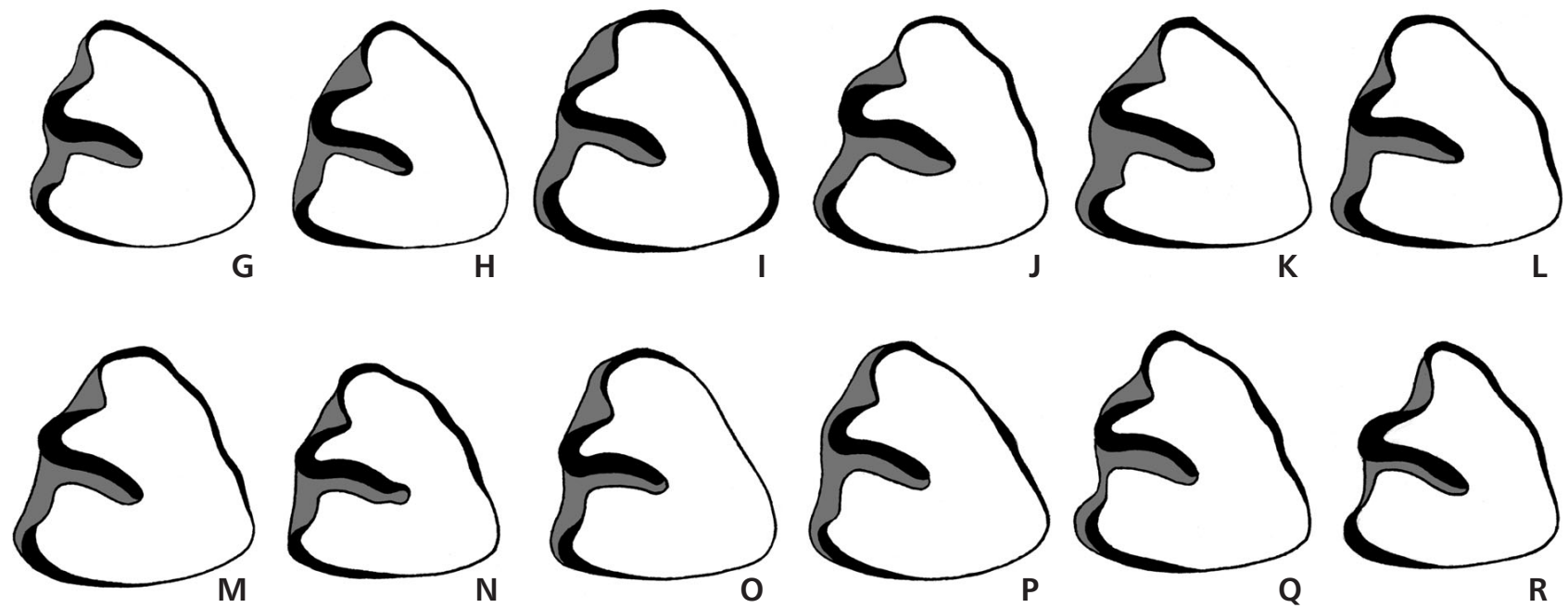

Figure 2. Morphology of $\mathrm{p} 3$ in Hypolagus from the Pliocene (Late Ruscinian-Ruscinian/Villányian boundary) localities of the Czech and Slovak Republics: A-H - Měňany 3, I-Q-Hostovce 2, and R-Ivanovce 1. All teeth are figured as left specimens (A, B, E-L and P-R are reversed). Scale bar: 3 mm.

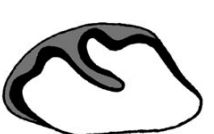

A
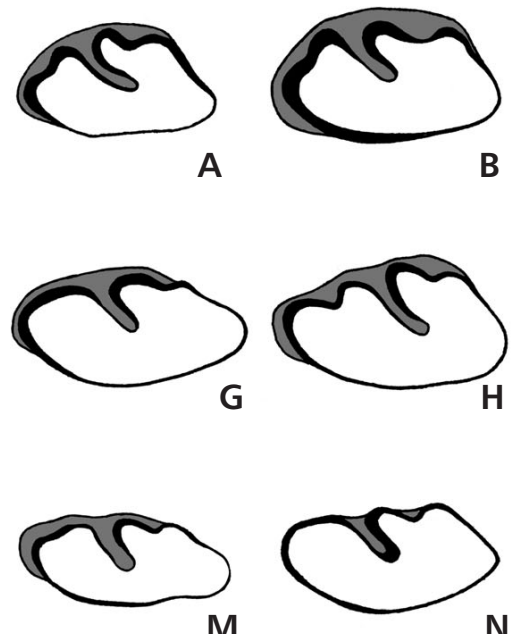

$\mathrm{N}$
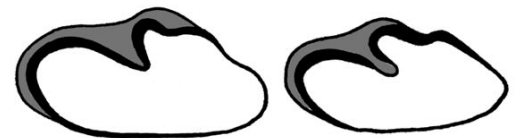

S

T

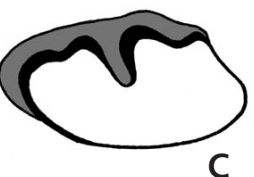

C
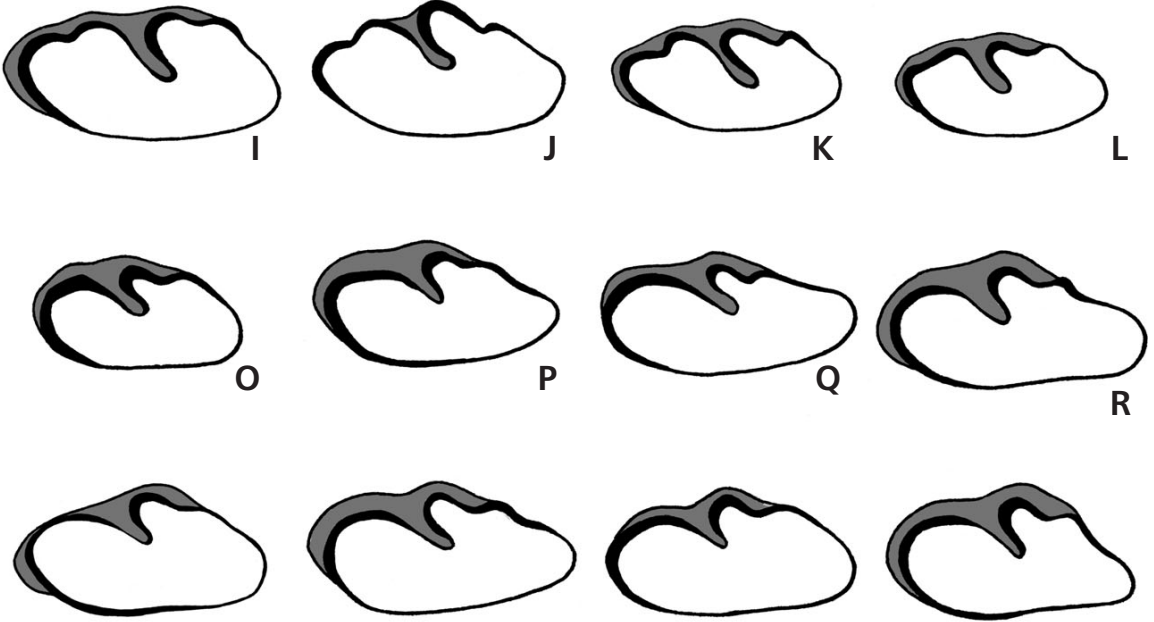

U
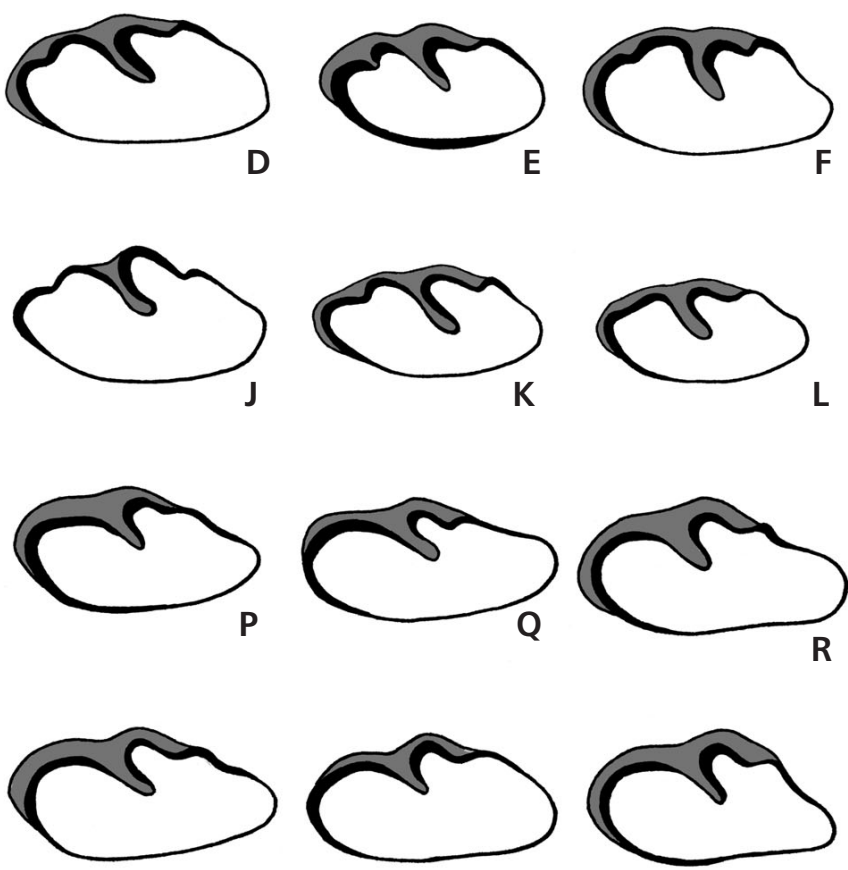

V
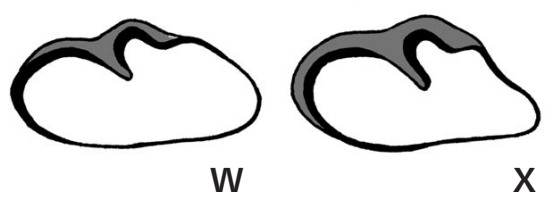

Figure 3. Morphology of $\mathrm{P} 2$ in Hypolagus from the Plio-Pleistocene (Late Ruscinian-Late Biharian) localities of the Czech and Slovak Republics: A - Chlum 4, B-F - Chlum 6, G - Měňany 2, H - Holštejn, I - Mladeč 1, J - Včeláre 4E, K-M - Včeláre 5, N - Včeláre 3/B3, O - Včeláre 7, P-T - Měñany 3, U-X - Hostovce 2. All teeth are figured as left specimens (A, D, E, I, K-O and S are reversed). Scale bar: $3 \mathrm{~mm}$. 
P2. - (1) The hypercone is of simple morphology without hypoflexus, the LL-morphotype I is significantly dominant (90\% of I, $10 \%$ of II; $\mathrm{N}=20)$. The LL-morphotytes III to $\mathrm{V}$ were not observed in the material from these localities. (2) In the lagicone, the shallow mesoflexus (the BMR-morphotype A) is always present (Fig. 3P-X).

p3. - (1) In the available material, the short and triangular (the trig-morphotype I) anteroconid is predominant ( $84 \% ; \mathrm{N}=25)$. Only in Měňany 3 , the transitional type of anteroconid (the trig-morphotype I/II) is present (e.g., Fig. 2F). The trig-morphotypes II to $\mathrm{V}$ were not observed in the material from Ivanovce 1, Hostovce 2, Měňany 3 and Hajnáčka I. (2) The buccal part of the hypoconid is almost exclusively limited to the clear type with edged margin ("beremendensis-Kante [edge]" sensu Fladerer 1987,), i.e. tal-morphotype "a" $(88 \% ; \mathrm{N}=25)$; the remaining specimens possess slight traits of tal-morphotype "b", or "c" (e.g., Fig. 2J, K), nevertheless, they can also be attributed to morphotype "a". (3) The interior part of the hypoflexid is predominantly simple (84\%; $\mathrm{N}=25)$ with uncrenulated enamel (the MBR-morphotype A). Morphotype E is absent in the available material.

In general, it can be observed in the p3 of Hypolagus from Hajnáčka I, Hostovce 2, Ivanovce 1 and Měňany 3 that the short and triangular anteroconid (the trig-morphotype I) is in most cases associated with an edged bucco-anterior margin of the hypoconid (the tal-morphotype "a") and simple interior part of hypoflexid (the MBR-morphotype A). The most numerous samples of P2 and p3 (Měňany 3 and Hostovce 2) were used for a morphodynamic analysis (sensu Fladerer \& Reiner 1996). Their morphodynamic indexes and positions within a twodimensional array of morphotypes are shown in Fig. 5B. In its size (Table 2), all the available first premolars fall clearly within the known variation range of the Pliocene species commonly referred to as " $H$. beremendensis" (sensu Fladerer 1987).

(Group B) The material obtained from Chlum 4, 6, 8, Gombasek, Holštejn, Lažánky 2, Mladeč 1, 3 - point [7/10], Stránská skála and Včeláre 4E, 5, 6/8, 10B exhibits the following specificities (Figs 3A-M, 4A-Z; Table 2).

P2. - (1) The hypercone is of simple morphology with shallow hypoflexus (the LL-morphotype IV is dominant (59\%; $N=17)$; (2) In the lagicone, the shallow mesoflexus (Fig. 3A-M) is always present, the BMR-morphotype A in $65 \%$ of cases $(\mathrm{N}=17)$. The morphotype association IV/B dominates in the available Biharian material from the Czech and Slovak Republics.

p3. - The morphotype composition of p3 is much more variable than in Hypolagus from Hajnáčka I, Hostovce 2, Ivanovce 1 and Měňany 3; all the above defined morphotypes (see "Material and methods" for details) are available in the Biharian sample. In the p3s of the Biharian Hypolagus from the studied area (1) the anteroconid is lin- gually widened with rather rectangular geometry, frequently flattened or with small infoldings on its anterior and/or antero-lingual sides (the distribution of trig-morphotypes I to $\mathrm{V}$ are 2, 0, 36, 28, 10 and $24 \%$, respectively; $N=50$ ). (2) In its morphology, the buccal part of the hypoconid is almost exclusively limited to the talmorphotypes " $b$ " to " $d$ "; the distribution of tal-morphotypes "a" to "e" are 2, 22, 54, 18 and 4\%, respectively; $\mathrm{N}=50$ ). A somewhat atypical enamel edge (on the antero-buccal side of the hypoconid) is visible in two specimens from Lažánky 2 and Včeláre 4E (Fig. 4C, U). (3) The interior part of the hypoflexid is predominantly simple $(62 \% ; \mathrm{N}=50)$ with uncrenulated enamel (the MBR-morphotype A). The shallower external re-entrant, the protoflexid, is very variable in its depth and morphology (Fig. 4); moreover, the extremely narrow and long protoflexid, atypical for the species, occurs in the material from Chlum 8 and Holštejn (Fig. 4N, O).

The most frequent p3 morphotype associations in the available Biharian material $(\mathrm{N}=49)$ of Hypolagus from the Czech and Slovak Republics are: II/c 20\% (II/c/A 10\%), III/c 16\% (III/c/A 12\%) and V/c 12\%. The most numerous samples of P2 and p3 (Chlum 6, 8 and Holštejn - supplemented with the new material) were used for a morphodynamic analysis (sensu Fladerer \& Reiner 1996). Their morphodynamic indexes and positions within a two-dimensional array of morphotypes are shown in Fig. 5B. In its size, all the available first premolars fall clearly within the known variation range of $H$. brachygnathus (Table 2).

The limited samples of Hypolagus from Měňany 2, Mokrá 1, Koliňany 1 and Včeláre 3/B3, 7 (Figs 3N, O, $4 A^{*}-D^{*}$; Table 2) cannot undoubtedly be attributed to either Group A or Group B. Their significant patterns of p3 variation and/or definite age correlation are/is still unknown. Moreover, actual knowledge on taxonomic or paleobiogeographic relations between known Central European taxa within the Late Villányian to Earliest Biharian period is still largely incomplete. Nevertheless, taking into account the available P2 and p3 morphotypes within the available sample, it seems more likely that the discussed specimens belong rather to an advanced form of Hypolagus, i.e. to the above Group B. Overall, more robust conclusions on their actual phenotypic attribution could be drawn only after more complete material will become available.

\section{Size and morphological changes of P2 and p3 over time}

Measurements of teeth in Hypolagus among the Ruscinian-Biharian samples from the Czech and Slovak Republics do not display significant differences (Table 2). In ac- 


$$
\begin{aligned}
& \text { कEहE } \\
& \text { वही०हत } \\
& \text { हो) है है } \\
& \text { हो हो हो है } \\
& \text { ही ही हह }
\end{aligned}
$$


Table 2. Teeth measurements of Hypolagus from the localities of the Czech and Slovak Republics.

\begin{tabular}{|c|c|c|c|c|c|c|c|c|c|c|}
\hline \multirow{3}{*}{ Locality } & \multicolumn{6}{|c|}{ p3 } & \multicolumn{4}{|c|}{$\mathrm{P} 2$} \\
\hline & & $\mathrm{L}$ & & W & & 1 & & $\mathrm{~L}$ & & W \\
\hline & $(\mathrm{N})$ & $\mathrm{M} \pm \mathrm{SD}$ & $(\mathrm{N})$ & $\mathrm{M} \pm \mathrm{SD}$ & $(\mathrm{N})$ & $\mathrm{M} \pm \mathrm{SD}$ & $(\mathrm{N})$ & $\mathrm{M} \pm \mathrm{SD}$ & $(\mathrm{N})$ & $\mathrm{M} \pm \mathrm{SD}$ \\
\hline 1. Chlum 4 & (1) & 3.39 & $(1)$ & 3.37 & (1) & 1.40 & & - & & - \\
\hline 2. Stránská skála & (1) & 3.20 & (1) & 3.05 & (1) & 1.35 & & - & & - \\
\hline 3. Lažánky 2 & (1) & 3.45 & (1) & 3.17 & (1) & 1.36 & & - & & - \\
\hline 4. Gombasek & $(6)$ & $3.17 \pm 0.23$ & (6) & $2.97 \pm 0.20$ & (6) & $1.27 \pm 0.09$ & & - & & - \\
\hline 5. Mladeč 3 & (1) & 3.00 & (1) & 3.25 & (1) & 1.25 & & - & & - \\
\hline 6. Chlum 6 & (6) & $3.40 \pm 0.12$ & $(6)$ & $3.21 \pm 0.18$ & (6) & $1.32 \pm 0.11$ & $(7)$ & $1.93 \pm 0.10$ & (7) & $3.57 \pm 0.23$ \\
\hline 7. Chlum 8 & (4) & $3.46 \pm 0.09$ & (4) & $3.34 \pm 0.11$ & (4) & $1.46 \pm 0.11$ & & - & & - \\
\hline 8. Měňany 2 & (1) & 3.42 & $(1)$ & 3.23 & (1) & 1.35 & (1) & 1.77 & (1) & 3.61 \\
\hline 9. Holštejn & (1) & 3.25 & $(1)$ & 3.20 & (1) & 1.41 & (1) & 1.90 & (1) & 3.50 \\
\hline 10. Mokrá 1 & (1) & 3.49 & $(1)$ & 3.33 & (1) & 1.44 & & - & & - \\
\hline 11. Mladeč 1 & (1) & 3.30 & $(1)$ & 3.06 & (1) & 1.25 & $(1)$ & 2.02 & (1) & 3.94 \\
\hline 12. Včeláre 4E & (6) & $3.63 \pm 0.16$ & $(6)$ & $3.44 \pm 0.18$ & (6) & $1.46 \pm 0.10$ & (1) & 1.86 & $(1)$ & 3.64 \\
\hline 13. Včeláre $6 / 8$ & (1) & 3.30 & $(1)$ & 3.14 & (1) & 1.40 & & - & & - \\
\hline 14. Včeláre 10B & (2) & $3.49 ; 3.60$ & $(2)$ & $2.94 ; 2.91$ & $(2)$ & $1.18 ; 1.10$ & & - & & - \\
\hline 15. Včeláre 5 & (1) & 3.79 & (1) & 3.55 & (1) & 1.41 & $(2)$ & $1.93 ; 1.59$ & (2) & $3.83 ; 3.24$ \\
\hline 16. Včeláre 3/B3 & (2) & $3.67 ; 3.26$ & $(2)$ & $3.55 ; 2.96$ & $(2)$ & $1.50 ; 1.20$ & & - & & - \\
\hline 17. Včeláre 7 & & - & & - & & - & (1) & 1.50 & (1) & 2.96 \\
\hline 18. Koliňany 1 & (1) & 3.59 & (1) & 3.35 & (1) & 1.30 & & - & & - \\
\hline 19. Hajnáčka I & (2) & $3.20 ; 3.28$ & (2) & $2.80 ; 3.10$ & (2) & $1.10 ; 1.39$ & (1) & 1.85 & (1) & 3.62 \\
\hline 20. Měňany 3 & (8) & $3.38 \pm 0.05$ & (8) & $3.29 \pm 0.15$ & (8) & $1.50 \pm 0.11$ & $(10)$ & $1.81 \pm 0.10$ & (10) & $3.53 \pm 0.25$ \\
\hline 21. Hostovce 2 & (13) & $3.46 \pm 0.17$ & (13) & $3.37 \pm 0.18$ & (13) & $1.47 \pm 0.12$ & (7) & $1.94 \pm 0.07$ & (7) & $3.72 \pm 0.11$ \\
\hline 22. Ivanovce 1 & (1) & 3.38 & $(1)$ & 3.20 & (1) & 1.40 & & - & & - \\
\hline
\end{tabular}

(Fostowicz-Frelik 2007a), is absent from the material from the Czech and Slovak Republics. While in the Late Ruscinian-Early Villányian localities under study, the morphotype A is exclusively present, in the Biharian ones, the morphotypes A and B are almost co-dominant. In the studied areas, morphotype B is found first in Včeláre 5.

p3. - (1-3) In the Late Ruscinia-Early Villányian samples under study, the predominant short and triangular anteroconid (the trig-morphotype I) is in most cases associated with an edged bucco-anterior margin of the hypoconid (the tal-morphotype "a") and simple interior part of the hypoflexid (the MBR-morphotype A) - Fig. 5Ca, b; in contrast to the Biharian ones, where advanced and predominantly p3 morphotypes II and III are in most cases associated with the hypoconid morphotype "c" and hypoflexid morphotype A (Fig. 5Ca, b). Thus, p3 geometry is becoming more rectangular with a widened anteroconid (Fig. 4A-Z).

Based on the studied material, the most discriminating criterion of p3 proved to be the morphology of the anteroconid associated with the morphology of the buccal part of the hypoconid (Fig. 5Ca). The remaining morphotype component of $\mathrm{p} 3$, the morphology of the interior part of the hypoflexid, does not display significant changes with time (Fig. 5Cb). In accordance with Fladerer (1987) and Fladerer \& Reiner (1996), the most discriminating criterion of $\mathrm{P} 2$ proved to be the morphology of the hypercone together with depth of hypoflexus. In the material under study, there is a significant difference between the Pliocene and Pleistocene samples (Fig. 5Cc). On the other hand, the second morphotype component of P2 - the lagicone is more conservative in its morphology. Its advanced morphotype B is already present in the Late Ruscinian (e.g., in Węże 1; Fladerer \& Reiner 1996, or Fostowicz-Frelik 2007a). In the studied palaeopopulation, the lagicone does not display significant differences or changes (Fig. 3).

Following morphodynamic analysis calculated from the sums of the products of the frequency of classes I-V of P2 and p3 and multiplicatory factors (sensu Fladerer \& Reiner 1996); the morphodynamic indexes of P2 and p3 occlusal pattern of Hypolagus from Měňany 3 and Hostovce 2 are close to that of Hypolagus from Węże 1 and Rębielice Królewskie 1 in Poland (Fig. 5B). While the Early Pleistocene Hypolagus from Chlum 6, 8 and Holštejn fall, due to its high frequency of advanced morphotypes, 

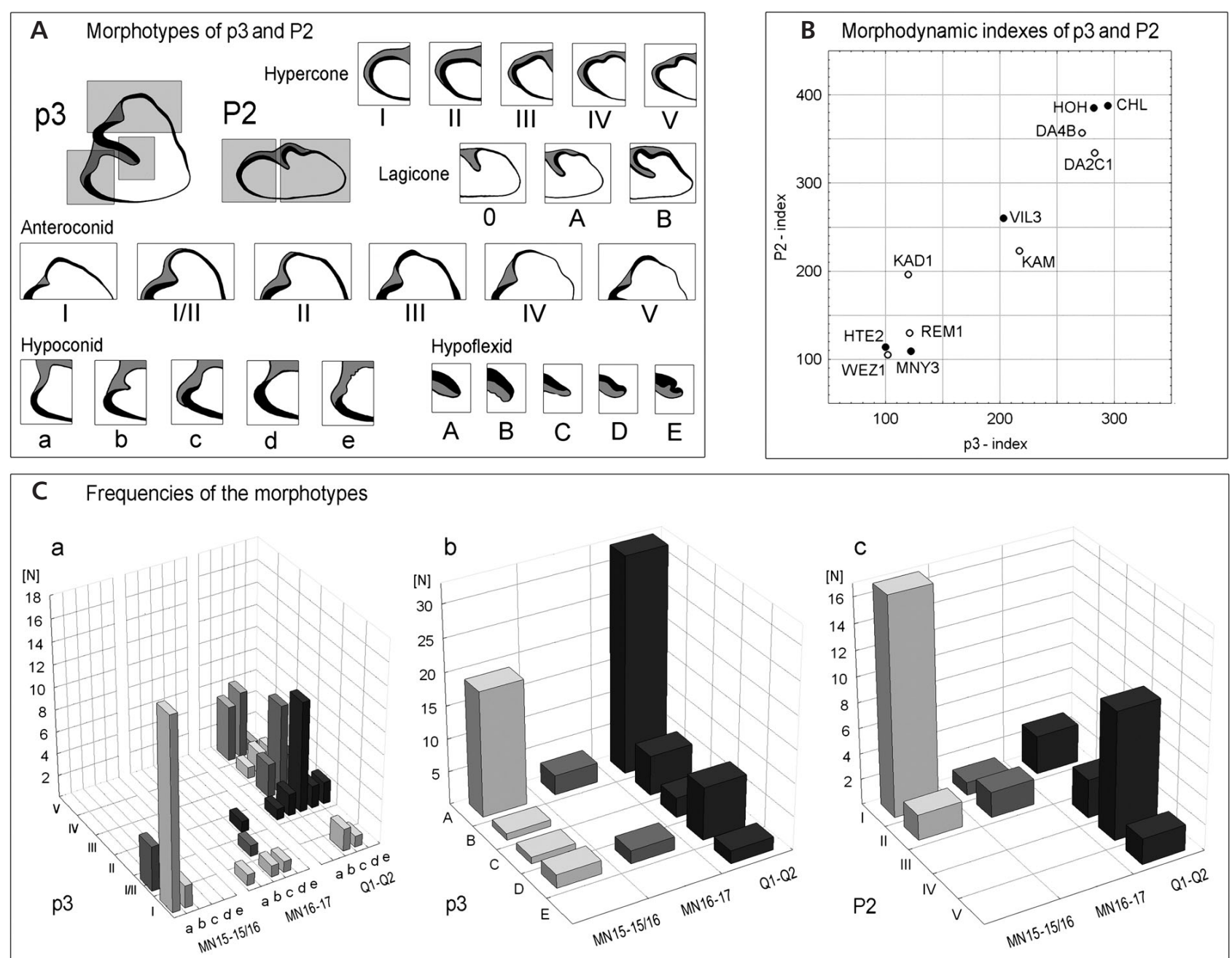

Figure 5. Morphological changes of $\mathrm{p} 3$ and $\mathrm{P} 2$ pattern in Hypolagus from localities of the Czech and Slovak Republics during the Late Ruscinian to Late Biharian. - A - morphotypes of enamel structures of P2 and p3 defined on the material under study: P2 - types I-V of hypercone (LL-types sensu Fladerer 1987), types 0, A and B of lagicone (BMR types sensu Fladerer 1987), p3 - types I-V of anteroconid (Trig-types sensu Fladerer \& Reiner 1996), types "a"-"e" of hypoconid (Tal-types "a"-"c" sensu Fladerer 1987, types "d" and "e" sensu Fladerer 1987 are merged here into type "d"; type "e" is the new category ), and types A-E of hypoflexid (MBR-types sensu Fladerer 1987). • B - twodimensional array of morphodynamic indexes of p3 and P2 (sensu Fladerer \& Reiner 1996), closed circles - new data, open circles - data provided by Fladerer \& Reiner 1996). Abbreviations: CHL - Chlum 6, 8 (CZ), DA4B - Deutsch-Altenburg 4B (A), DA2C1 - Deutsch-Altenburg 2C1 (A), HOH - Holštejn (CZ), HTE2 - Hostovce 2 (SK), KAD1 - Kadzielnia 1 (P), KAM - Kamyk (P), MNY3 - Měňany 3 (CZ), REM1 - Rębielice Królewskie 1 (P), VIL3 - Villány 3 (H), WEZ1 - Węże 1 (P). • C (a-c) - the diagrams showing the frequency of $\mathrm{p} 3$ and $\mathrm{P} 2$ morphotypes: $\mathrm{a}$ - anteroconid to hypoconid morphotypes of $\mathrm{p} 3, \mathrm{~b}$ - morphotypes of the interior part of $\mathrm{p} 3$ hypoflexid, $\mathrm{c}$ - hypercone morphotypes of $\mathrm{P} 2$.

within the advanced $H$. brachygnathus, slightly more advanced compared with Hypolagus from DeutschAltenburg 2C and 4B in Austria (Fig. 5B). Differences in depth of the protoflexid (AER-factor sensu White 1991) between the Pliocene and Pleistocene taxa, presented by Fostowicz-Frelik 2003 as the most discriminatig p3 character, were not proved in the material under study. Nevertheless, this result was based on a relatively small sample and may not be fully representative. Overall, in Hypolagus from the Biharian localities under study, the depth and morphology of the $\mathrm{p} 3$ prototoflexid are much more variable than in more ancient Hypolagus from Hajnáčka I,
Hostovce 2, Ivanovce 1 and Měňany 3 (compare with Figs 2, 4); this feature of the protoflexid is determinable based on the relatively small sample.

\section{Discussion and conclusions: A synoptic survey of the genus Hypolagus}

In the taxonomic investigations of Hypolagus, as well as other leporid genera, authors traditionally attached significance to the structures of $\mathrm{P} 2$ and $\mathrm{p} 3$ and eventually the mandible, as discriminant criteria (e.g., Dice 1929, Kormos 
1934, Hibbard 1963, Radulesco \& Samson 1967, Fladerer 1987, White 1991, White \& Morgan 1995, Fladerer \& Reiner 1996, Voorhies \& Timperley 1997, Fostowicz-Frelik 2003 , etc.). Only minor attention was paid to structures of the postcranial skeleton of the genus (Sych 1965, Fladerer 1984, or Fostowicz-Frelik 2007b). This is mainly because of the abundance of teeth in fossil records, while postcranial bones are relatively scarce and/or very fragmentary. The relatively high intraspecific and ontogenetic variability of traits is another handicap. Thus postcranial remains are rarely useful in the case of small samples, i.e. in most cases of finds in real practical paleontology. This is also the case of the fossil record of Hypolagus reported here from twenty-two fossil localities in the Czech and Slovak Republics where the remains found in each locality were usually in small amounts, incomplete and mainly in the form of isolated teeth.

However, the above text demonstrates that two distinct phenotypic entities of Hypolagus can be clearly distinguished in the Pliocene and Pleistocene localities of the Czech and Slovak Republics as well as in other regions of Central Europe (e.g., Fladerer 1987; Fladerer \& Reiner 1996; Fladerer \& Fiore 2003; or Fostowicz-Frelik 2003, 2007a); one group (Group B) shows a considerable amount of derived characters in the premolar structures and the other (Group A), which in this respect is apparently quite primitive. These entities show at the same time differences in the stratigraphical contexts of the site which they come from. In accordance with common usage (see Fladerer 1987), the advanced form is also here denoted, with nomenclatural modifications (see below), as H. brachygnatus. Nevertheless, as far as the name of the primitive group is concerned, the situation is much less transparent. For that reason, the above used name $H$. beremendensis, commonly applied in other literature, was written in quotation marks, an explanation is given below.

\section{The problem of names for the Central European Hypolagus species}

Salamon János Petényi (1799-1855) - a founder of Hungarian research on the Plio-Pleistocene faunas in the Villany Mountains, was obviously the first who discovered this European fossil taxon. The first short information related to this taxon appeared in a published letter by H. von Meyer (1851, p. 679) to H.G. Bronn dated 21 June; partly mentioned in Petényi's work $(1864$, pp. 79,80$)$ - posthumously completed and edited by Ferenc Kubinyi. Nevertheless, the new specific name in Latin - "beremendensis" for these leporid fossil remains from the Beremend area, was first used by Koch (1900, p. 455); most probably based on the unpublished part of Petényi's manuscript ( $c f$. Kretzoi 1962 and Jánossy 1963).
In the following years, T. Kormos, a geologist of the Hungarian Geological Survey, reported fossil leporid remains from Püspökfürdő (= Betfia), Brassó, Csarnóta and Nagyharsányhegy (Kormos 1911, 1914a, b, 1920). At this time, he was aware of two different fossil forms referring them to the genera Oryctolagus and/or Lepus. Later, Kormos (1930) mentioned two new species names from fossil sites of Püspökfürdő, Somlyóhegy (= Betfia sensu Kretzoi 1941b) - localities II (= Hauptfundstelle), IV and Höhlenausfüllung sensu Kormos 1914a, b [the German part]). He reported there the material from Püspökfürdő Hauptfundstelle and Höhlenausfüllung, previously referred ( $c f$. Kormos 1914b) to as Oryctolagus cuniculus, newly as "Oryctolagus beremendensis n. sp.". The fossil material from Püspökfürdő - locality IV, previously referred to as Lepus europaeus (cf. Kormos 1914b) was moved into the newly described species - "Lepus brachygnathus n. sp." (see below for details). Subsequently, he (Kormos 1934) provided a revision of the previously mentioned leporid material from the above localities, and based on the new material from Villány Kalkberg (in the later literature Villány 3 - sensu Kretzoi 1956b), he described new taxa; (1) a new genus and species Pliolagus beremendensis (= "Oryctolagus beremendensis" sensu Kormos 1930), and (2) a new species "brachygnathus" as Hypolagus brachygnathus (= "Lepus brachygnathus" sensu Kormos 1930). He did not regard the previous work from 1930 as a description of new taxa "Oryctolagus beremendensis" and "Lepus brachygnathus" (Kormos 1930 [1931], p. 237, and 1934).

The genus Pliolagus was accepted by some authors (e.g., Kretzoi 1941b - erected a new species Pliolagus tothi, 1956b, Kowalski 1958a, and Shushpanov 1977) as valid. Sych (1965, pp. 62-69) synonymized this genus with Hypolagus Dice, 1917 and this generic synonymy has been generally accepted to date. Until Fladerer (1987), the Central European populations of Hypolagus had been regarded as a single taxonomic taxon (e.g., Sych 1965, Fladerer 1984, etc.). Fladerer's (1987) distinction into two independent taxa within the Plio-Pleistocene of Central Europe was subsequently followed by Fladerer \& Reiner (1996) and Fostowicz-Frelik (2003) on the sub-species level; and by Fladerer \& Fiore (2003) and Fostowicz-Frelik (2007a, b) on the species level.

A complete list of the known unavailable and available names, with revision, produced from 1930 to the present is as follow:

Oryctolagus beremendensis in Kormos (1930) [nomen nudum]. - (a) An unavailable name; the name (in Kormos 1930 ) is accompanied only by a statement: “... [it] bears ancient features ..." (Kormos 1930, p. 46; translated from Hungarian). Neither any evaluative criterion (even a subjective one; compare e.g. with Čermák 2007, p. 253) nor 
any indication (in a sense of Article 12.2) is provided there. Therefore, this first usage of the name fails to conform to Article 12 of ICZN (1999) and it must be regarded as a nomen nudum (contra Fostowicz-Frelik 2007a, pp. 549-552). (b) A holotype was not designated, (c) the name was used by Kormos (1930) for the leporid material from Püspökfürdő, Somlyóhegy (= Betfia) referred to formerly by Kormos (1914b) as Oryctolagus cuniculus - i.e. the material from the Early Biharian localities II and "Höhlenausfüllung"; and leporid remains from the area of the Villany Mountains (a particular locality (compare with Kormos 1911, 1914a, b, 1920) was not specified by Kormos (1930) and cannot be identified now).

This first usage of the name was not generally considered (not even by Kormos; see e.g., 1930 [1931], p. 237, and 1934) as a description. On the other hand, Fostowicz-Frelik $(2007 a, b)$ considered the name as valid. She believed that specimen No. Ob/3691 (Fig. 6Da, Db) from the Late Villányian locality Villány - Kalkberg, i.e. the particular locality from the area of the Villány Mountains (she uses the term Villány for the "type locality"; Fostowicz-Frelik 2007a, p. 551), is the holotype and states: "... It is almost certainly the specimen on which Kormos based the description of the new species in 1930. It should be therefore regarded as the holotype. ..." (FostowiczFrelik 2007a, p. 549). Nevertheless, (1) Kormos's work from 1930 was published in April, while the only available and deformed fragment of skull (compare with Kormos 1934 and Fig. 6Da, Db here), obviously identical with the specimen No. Ob/3691, appeared in his hand in August 1930 (Kormos 1934, p. 71 [only in the German part]), thus this specimen could not be included by T. Kormos in the material published in 1930. (2) Kormos (1930) discussed the leporid material from Püspökfürdő Somlyóhegy (= Betfia, Romania), whilst the area of the Villány Mountains, Hungary was mentioned only marginally (Kormos 1930, p. 46). There is no evidence, published or available unpublished, to determine undoubtedly which particular localities or specimens from the Villány Mountains were included by T. Kormos in his (1930) paper. Moreover, (3) a holotype can only be fixed in the original publication and by the original author (Article 73.1.3 of ICZN 1999) while Kormos (1930) did not use the term holotype or an equivalent expression (Article 73.1.1); it also cannot be regarded as holotype fixation by monotypy in accordance with Article 73.1.2. Thus the usage of the term "holotype" in Fostowicz-Frelik (2007a, pp. 549, 550) must be regarded as unjustified. In any case the name Oryctolagus beremendensis in Kormos (1930) must be regarded as a nomen nudum.

Lepus brachygnathus Kormos, 1930. - (a) An available name; the indication [a bibliographic reference to the illustration (Pl. II) in Petényi 1864] in Kormos (1930, p. 46) fulfils the conditions of Article 12.2.7 of ICZN (1999). (b) A holotype was not designated, (c) the type series includes (Article 72.4.1 of ICZN 1999) the remains figured in Pl. II of Petényi (1864) - the only specified material from the area of the Villány Mountains (Kormos 1930); and leporid material from Püspökfürdő, Somlyóhegy (= Betfia) referred to by Kormos (1914b) as Lepus europaeus (i.e. the material from the Early Biharian locality IV).

This first usage of the name in Kormos (1930) was generally considered as unavailable. Fostowicz-Frelik (2007a), for the first time, rightly mentioned the availability of the name (description by an indication). But, (1) she incorrectly applied/interpreted Article 12.2.7 and cited "(Petényi, 1864)" as the original author and date of the taxon; i.e., Hypolagus brachygnathus (Petényi, 1864). However, the author of a name is the person who first publishes it in a way that satisfies the criteria of availability (Article 50.1 of ICZN 1999) and that is, in this context, the work indicating not indicated. Then the author of the specific name "brachygnathus" is deemed to be "(Kormos, 1930)". Unfortunately, the type series, as defined by Kormos (1930), is missing (see below). At the same time, the neotype designation provided by Fostowicz-Frelik (2007a) fails to conform to the mandatory provisions of Articles 75.3.4 and 75.3.6 of ICZN (1999), and must therefore be regarded as invalid. Nevertheless, the present author considers that a validly designated name-bearing type is necessary to define the nominal taxon objectively and to ensure the stability of the below proposed nomenclatural acts; thus he provides the valid designation of the neotype in this paper (see below).

Pliolagus beremendensis Kormos, 1934. - (a) An available name; the description provided by Kormos (1934) fulfils the conditions of Article 13.1.1 of ICZN (1999). (b) The holotype (the left juvenile mandible with p3-m3; No. $\mathrm{Ob} / 3931$ (Fig. 6Ca-Ce); deposited in HNHM) was designated from the Late Villányian (MN 17) locality Villány Kalkberg (= Villány 3).

The name is generally considered as available. In addition to the original description, Pliolagus was also treated as an independent genus (by e.g., Kretzoi 1941b, 1956b; Kowalski 1958a; and Shushpanov 1977). On the other hand, Sulimsky (1964) and Sych $(1964,1965)$ - later followed also by Fladerer \& Reiner (1996) or Fostowicz-Frelik (2003) - synonymized the genus Pliolagus Kormos, 1934 with Hypolagus Dice, 1917. Within the genus Hypolagus, the taxon was synonymized tentatively by Fladerer (1987, p. 130) and definitely by Fostowicz-Frelik (2007a, p. 550) with the primitive form referred to as "Hypolagus beremendensis".

Hypolagus brachygnathus Kormos, 1934. - (a) An available name; the description provided by Kormos (1934) fulfils the conditions of Article 13.1.1 of ICZN (1999). 
(b) The holotype (the left mandible with p3-m3; No. $\mathrm{Ob} / 3689$; deposited in MAFI) was designated from the Late Villányian (MN 17) locality Villány - Kalkberg (= Villány 3).

The nominal taxon Hypolagus brachygnathus Kormos, 1934 was established based on a different name-bearing type than Lepus brachygnathus Kormos, 1930. The former was generally considered as the oldest available name for Central European taxa; until Fladerer (1987), these populations of Hypolagus were regarded as a single taxonomic taxon. Kretzoi (1955, 1956a, b, 1962, 1965; followed also by Jánossy 1963 or Fladerer 1984) considered Hypolagus brachygnathus Kormos, 1934 as a junior synonym of "Hypolagus beremendensis (Petényi, 1864)" (see below); and the name Lepus brachygnathus Kormos, 1930 as a nomen nudum (Kretzoi 1956b, p. 148).

Kretzoi (1941b; held also in 1954, 1955, 1956a, b, 1965) proposed for the European taxa the generic name "Lagotherium Croizet \& Jobert, 1828" (compare with Kretzoi 1941b and 1965) instead of Hypolagus Dice, 1917; this view was variously held also by Thenius (1948), Heller (1956), Koby (1960), Sulimski (1962) and Jánossy (1986). In any instance, neither the generic name "Lagotherium" nor any other scientific name (Articles 11.2 and 11.3) pertaining to leporid remains is present anywhere in Croizet \& Jobert (1828) - contra Fostowicz-Frelik (2007a, p. 549); apart from the triple mention (Croizet \& Jobert 1828, pp. $89,90,159)$ of the French expression "lièvre" or "lapin". The first usage of the name "Lagotherium" is by Croizet in Pictet (1853, p. 256); the fact mentioned also by e.g. Palmer (1904) or McKenna \& Bell (1997). Nevertheless, the status of Lagotherium, both taxonomic (e.g., Kretzoi 1941b, McKenna \& Bell 1997 versus Schreuder 1937, Fladerer 1987) and nomenclatural (i.e., the availability of Croizet's names Lepus issiodorensis and $L$. neschersensis in Croizet \& Jobert 1828), remain obscure. This problem is beyond the scope of this paper and needs further revisions, including the potential suppression of the name Lagotherium by a ruling of the Commission (in a sense of Articles 23.2 and 23.9.3).

Pliolagus tothi Kretzoi, 1941. - (a) An available name; the description provided by Kretzoi (1941b, pp. 322, 323) fulfils the conditions of Article 13.1.1 of ICZN (1999). (b) A holotype was not designated, (c) specimens with a name-bearing function originated from the Early Biharian (the Betfia stage) locality Betfia V.

The name is generally considered as available. A historical overview of taxonomy of Pliolagus tothi, similar to the above mentioned Pliolagus beremendensis, is given below.

The specimens (collections of MAFI) from the type locality and most probably from the type series (sensu Kretzoi 1941b) were studied in detail by Sych (1965, pp. 62-69). Unfortunately, at present, no leporid material from Kretzoi's original collection from the type locality is available in MAFI (L. Kordos, in litt.). Nevertheless, neither the designation of a holotype in Kretzoi (1941b) nor later designation of a lectotype (in a sense of Article 74) has been provided yet; thus the present author designates (see below) the lectotype in this paper to objectively define this nominal taxon.

"Hypolagus beremendensis Fladerer, 1984". - (a) The availability of the name is controversial; in the opinion of the present author the name could be accepted as available with the first description provided by Fladerer (1984) fulfilling the conditions of Article 13.1.1 of ICZN (1999). (b) The name-bearing type was not designated, thus a bearer of the name should be the type series that consists of all the specimens included by the author in the taxon (compare with Article 72.4.1 of ICZN 1999).

All the earlier usages of the specific name "beremendensis" (in the context of the discussed nominal taxon) before Fladerer (1984) undoubtedly fail to conform to the mandatory provisions of Article 12 or 13 of ICZN (1999) and must be regarded as nomina nuda. Fladerer (1984) accepted the nomenclatural results of Kretzoi (1962), and considered the work of Petényi (1864) as a valid description of "Lepus beremendensis" (the name firstly used by Koch 1900), consequently Hypolagus brachygnathus Kormos, 1934 as its junior synonym; at that time, he followed Kretzoi 1962 and Sych 1965 and he held the taxonomical view of Central European taxa being a single taxonomic taxon. Nevertheless, neither the specific name "beremendensis" nor another scientific name (Articles 11.2 and 11.3) pertaining to leporid remains is present anywhere in Petényi (1864) (the fact firstly mentioned by Kretzoi 1962, p. 358). Kretzoi (1962) and Jánossy (1963) most probably accepted the usage of the specific name "beremendensis" in Koch (1900, p. 544 - ordinal number 64) as a description by indication and incorrectly applied Article 12.2.7 (see above for the explanation). Nevertheless, Koch (1900) did not provide any indication or description in accordance with Article 12 of ICZN (1999), he did not even specify and/or refer to Petényi's specific work or illustration (Article 12.2). The mention of "locality" does not in itself constitute a description, definition, or indication (Article 12.3). Thus, the usage of the specific name "beremendensis" in Koch (1900) must be regarded as a nomen nudum. Due to the above mentioned facts, usages of the terms "holotype" in Fladerer \& Fiore (2003, p. 54) and "type locality" in Fladerer (1987, p. 130), Fladerer \& Reiner (1996, p. 154) and Fladerer \& Fiore (2003, p. 54) must be regarded as unjustified; a holotype can only be fixed in the original publication and by the original author (Article 73.1.3 of ICZN 1999), subsequently, the type locality of a nominal species-group taxon is the origin of the 
name-bearing type (Articles 76.1 and 73.2.3 of ICZN 1999). The last attempt at nomenclatural revision of this name was provided by Fostowicz-Frelik (2003), she followed the taxonomic concept of Fladerer \& Reiner (1996); i.e. the taxon as a more primitive chronosubspecies of "H. beremendensis (Petényi, 1864)". She stated (Fostowicz-Frelik 2003, p. 206) that the specimen No. Ob/3689 from Villány-Kalkberg (compare with Article 76.1) is a holotype (a contradiction with Article 73.1.3, see above) of " $H$. beremendensis (Petényi, 1864)", but on the following page (Fostowicz-Frelik 2003, p. 207) she stated: “...The original specimen illustrated by Petényi [the material from Beremend; compare with Article 76.1] is missing, but the type specimen of Hypolagus brachygnathus, the left mandible with teeth, No. Ob/3689, from Villány, described by Kormos (1934), is kept in the Geological Museum of the Hungarian Academy of Sciences, and should be accepted as lectotype [a contradiction with Article 74.1, compare with Article 72.4.1] of Hypolagus beremendensis..."; thus for two taxa $H . b$. beremendensis and $H$. b. brachygnathus, both valid in her opinion, she accepted the identical name-bearing type. In this sense, the names should be objective synonyms (compare with ICZN 1999). Later, Fostowicz-Frelik (2007a) withdrew this opinion and proposed the other, above discussed, nomenclatural results.

\section{Nomenclatural consequences}

In conclusion, for the current usage of the proposed names and their combinations, the above mentioned facts bring the following consequences:

The usage of the name Oryctolagus beremendensis in Kormos (1930) fails to satisfy Article 12 of ICZN 1999 and is to be regarded as a nomen nudum.

Kormos's paper from 1930 is to be accepted as a valid description of Lepus brachygnathus (description by an indication; Article 12.2.7 of ICZN 1999). No name-bearing type specimen(s) (i.e. holotype, lectotype, syntype or prior validly designated neotype) is available (see below). The present author considers that a name-bearing type is necessary to define the nominal taxon of Lepus brachygnathus Kormos, 1930 objectively, and due to the above mentioned reasons, there is an exceptional need for a validly designated neotype. Thus, accepting the decision of Fostowicz-Frelik (2007a), the specimen No. Ob/3689 (Fig. 6Aa-Ad) deposited in MAFI is designated here as a neotype for Lepus brachygnathus Kormos, 1930 with the following particulars: (a) Article 75.3.1. The neotype is designated here to clarify the taxonomic status of the nominal taxon of Lepus brachygnathus Kormos, 1930. (b) Article 75.3.2. The neotype differs from the relevant taxa by the combination of discriminant features provided by
Fladerer 1987, p. 136 (fig. 8a) for taxonomically significant p3 (primarily the morphology of the buccal part of the hypoconid) and by Fostowicz-Frelik (2007a, p. 552) for the mandible. Note that fig. 9c provided by Fostowicz-Frelik (2007a, p. 551) do not properly replicate the occlusal pattern of p3 of the neotype (compare with Fladerer 1987, fig. 8a and Fig. 6Aa here). (c) Article 75.3.3. The neotype specimen is the left mandible with $\mathrm{p} 3-\mathrm{m} 3$ catalogued under number No. Ob/3689 in the MAFI collections (Fig. 6Ab-Ad). The label provided by Kormos is contained in the box with the specimen. (d) Article 75.3.4. The name-bearing type consists of the specimens figured in Plate II of Petényi (1864) and leporid material from Püspökfürdő, Somlyóhegy (= Betfia) locality IV (Kormos (1914b, 1930); both the localities are no longer in existence. Moreover, the remains from localities I, III and IV of Betfia (situated in the vicinity of the main locality II) were not separated off from locality II; the exact locations of the localities are unknown (M. Venczel, personal communication in Betfia). The present author physically checked all the available material, both cataloged and uncataloged, in the collections of MAFI and HMNH, and no specimen could undoubtedly be identified with the name-bearing type. The results are supported by L. Kordos and M. Gasparik (personal communications). The present author was also in a position to study the newly found leporid material (collections of HMNH), that is believed to be a part of Petényi's orginal collection (J. Pálfy, personal communication). Nevertheless, no remain can be identified with any specimen figured in Plate II of Petényi (1864). Petényi’s original material, taking into account the records in Meyer (1851) and Petényi (1864), is also missing from the collections of SMF (G. Storch, in litt.). Thus, the present author has well-grounded reasons for believing the name-bearing type specimens to be lost. (e) Article 75.3.5. Kormos (1930) did not provide any discriminant diagnosis. The only specified name-bearing type figured in Plate II of Petényi (1864) bears no diagnostic features (FostowiczFrelik 2007a). Nevertheless in late 1930, Kormos (who did not consider the work published in April 1930 as a description; Kormos 1930 [1931], p. 237 and 1934) was preparing a description of Hypolagus brachygnathus (in his view the same taxonomic taxon as Lepus brachygnathus mentioned in 1930) and selected this specimen as the type (the label written by Kormos; J. Pálfy personal communication); later, published in Kormos (1934). From the strict nomenclatural point of view, Hypolagus brachygnathus Kormos, 1934 is regarded here as a separated nominal taxon (see above). Thus, the neotype is undoubtedly consistent (see also articles "b" and "f" here) with what is known of the former name-bearing type and with Kormos's taxonomical intentions and view of the taxonomic taxon. (f) Article 75.3.6. The neotype of Lepus brachygnathus Kormos, 1930 originates from the Late Villányian (MN 17) locality 
Villány-Kalkberg (e.g., Kormos 1930 [1931], 1934; Fladerer 1987, etc.), i.e. from the area of the Villány Mountains explicitly mentioned by Kormos (1930, p. 46). A part of the type locality of Lepus brachygnathus Kormos, 1930 (defined by Kormos 1930 in a sense of Articles 73.2.3 and 76.1) lies within this area; its stratigraphic span is the Villányian - Biharian. (g) Article 75.3.7. The neotype (No. Ob/3689) is deposited in the collections of the Geological Museum of the Hungarian Academy of Sciences (MAFI) in Budapest.

In the sense of Articles 74.7 and 74.4 and Declaration 44, I hereby designate the specimen figured (Article 74.4) in Kretzoi (1941b, pp. 251-322, fig. 6/1-2; Article 74.7.2) as a lectotype (Article 74.7.1 and Declaration 44) of the nominal taxon of Pliolagus tothi Kretzoi, 1941, described from the Biharian (the Betfia stage) locality Betfia 5. The lectotype is designated here to clarify the taxonomic status of the nominal taxon of Pliolagus tothi Kretzoi, 1941 (Article 74.7.3); p3 of the lectotype possesses clearly advanced morphotypes of the anteroconid and buccal part of the hypoconid (i.e., V/d on the occlusal side and II/c on the root side) typical for Hypolagus brachygnathus (Kormos, 1930), i.e. the only available species in the Biharian sites of Betfia (see above for additional information).

Sych (1965) revised the type material of both species of Pliolagus. He recognized the specimens as juvenile representatives of Hypolagus and synonymized them with Hypolagus Dice, 1917. It stands to reason that the relatively deep posterointernal reentrant of p3 in the holotype of Pliolagus beremendensis Kormos, 1934 is a result of unfinished ontogenetic transformation of the tooth, disappearing with wear in more adult stages (Averianov \& Tesakov 1997). Pliolagus beremendensis Kormos, 1934 and $P$. tothi Kretzoi, 1941 were synonymized, tentatively by Fladerer (1987, p. 130) and definitely by FostowiczFrelik (2007a, p. 550), with the primitive form referred to as "Hypolagus beremendensis". Nevertheless, taking into account (1) p3 morphology of the holotype, as well as (2) phenotypic pattern of teeth from all the available specimens from the relevant Kormos's collections from Villány 3; the type specimen (Fig. 6Ca-Ce) from the Late Villányian locality Villány 3 cannot be attributed to the primitive form of Hypolagus. The p3 of the holotype (No. Ob/3931; Fig. 6Ca-Cb) possesses, on both occlusal and root sides, relatively advanced morphotypes of widened anteroconid (I/II-II) and buccal part of the hypoconid ("c"-"d"). This is also true for the rest of the specimens from Kormos's collections from Villány 3 where the morphotypes I/II-II (with significantly widened anteroconid) and "c"-"d" of p3 $(\mathrm{N}=30)$ are available almost exclusively [i.e. in the material No. Ob/3690 (1-15) and No. Ob/4798 (1-12) from MAFI; and V61/2157 (1-8) from HMNH labeled by Kormos as "cotypus" of $H$. brachygnathus Korm., i.e. most probably the sample from which the specimen
No. Ob/3689 (here the neotype) originates]. Whereas, the well-defined morphotypes I and "a" of p3, typical for the primitive form of Hypolagus, are totally absent in Kormos's sample from Villány 3. The name-bearing type of Pliolagus tothi Kretzoi, 1941 from the Biharian (the Betfia stage) locality Betfia 5, also possesses a wide anteroconid (with slight traces of depressions) associated with the non-edged buccal part of the hypoconid (the morphotypes "c"-"d"). This is in accordance with the known morphotype composition of $\mathrm{p} 3$ from Betfia sites of the same age (collections of MAFI, HMNH, and the author's comparative sample from Betfia in situ), where the exclusive appearance of advanced morphotypes I/II-V and "b"-“d", typical for H. brachygnathus (Kormos, 1930) are present.

Thus, the nominal taxa of Pliolagus beremendensis Kormos, 1934 and Pliolagus tothi Kretzoi, 1941 are regarded here as junior subjective synonyms of Hypolagus brachygnathus (Kormos, 1930) - contra Fostowicz-Frelik (2007a, p. 550).

Due to the above provided nomenclatural acts, Hypolagus brachygnathus Kormos, 1934 is regarded here as a junior objective synonym (the same name-bearing type) and simultaneously as a junior secondary homonym of Hypolagus brachygnathus (Kormos, 1930).

In case of acceptance of the name "Hypolagus beremendensis Fladerer, 1984" as available, then it would have to be regarded as a junior secondary homonym of Hypolagus beremendensis (Kormos, 1934). Unfortunately in Fladerer (1984), there is no unimpugnable description accompanied by an unambiguously defined and taxonomically suitable type series. In general until now, the more primitive Central European taxon of Hypolagus has not been defined objectively. Nevertheless, no physically available and taxonomically suitable specimen can be undoubtedly used in the sense of Article 74.1 and the taxonomical/historical view of the species. Thus, the potential nomenclatural acts in a sense of the mandatory provisions of Articles 74.1 and 23.3.5 do not fully solve this nomenclature/taxonomic problem and could be impugned. Thus, the present author has well-grounded reasons for erecting a new species from the Pliocene of Hungary as the most appropriate and stable nomenclatural act (see below).

\section{Taxonomy of the Central European Hypolagus species}

Order Lagomorpha Brandt, 1855

\section{Genus Hypolagus Dice, 1917}

Type species. - Lepus vetus Kellogg, 1910; by original designation. 


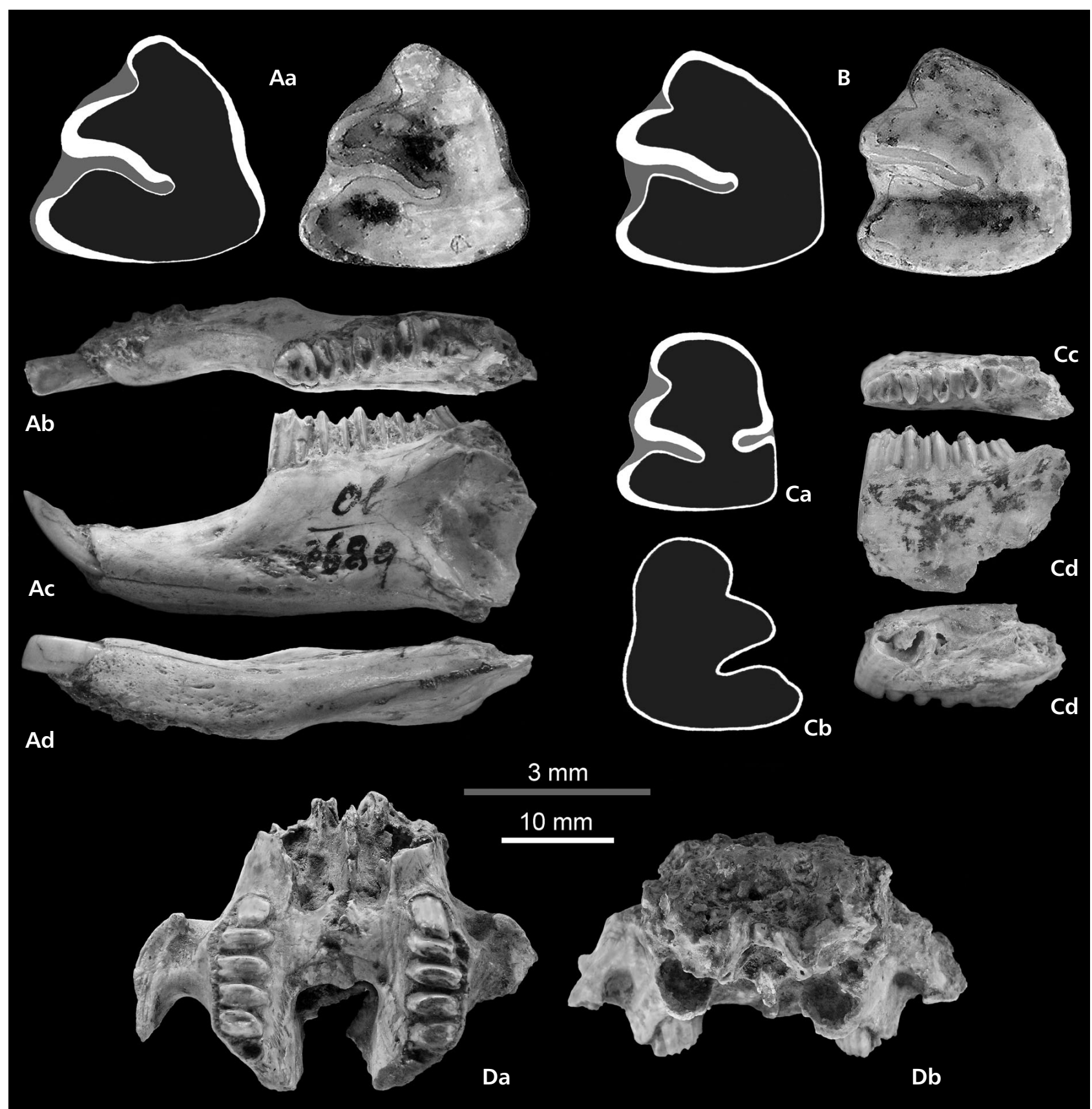

Figure 6. Nomenclaturally important specimens related to the Central European Hypolagus taxa. • Aa-Ad - neotype (No. Ob/3689) of Hypolagus brachygnathus (Kormos, 1930) - fragment of left mandible with i1 and p3-m3 from the Late Villányian (MN 17) locality Villány 3; Aa - occlusal view of p3 enamel pattern, Ab-Ad - mandible, Ab - dorsal view, Ac - buccal view, Ad - ventral view. $\bullet$ B - holotype (No. Ob/4757) of Hypolagus petenyii Čermák \& Fladerer sp. nov. - left p3 from the Early Villányian (MN 16) locality Beremend, B - occlusal view of p3 enamel pattern. $\bullet$ Ca-Ce - holotype (No. Ob/3931, or V61/1376) of Pliolagus beremendensis Kormos, 1934 - left juvenile mandible with p3-m3, Ca - occlusal view of p3 enamel pattern, $\mathrm{Cb}$ - root view of $\mathrm{p} 3$ enamel pattern, $\mathrm{Cc}-\mathrm{Ce}-$ mandible, $\mathrm{Cc}$ - dorsal view, $\mathrm{Cd}$ - buccal view, $\mathrm{Ce}$ - ventral view. $\bullet \mathrm{Da}, \mathrm{Db}-\operatorname{specimen}(\mathrm{No} . \mathrm{Ob} / 3691)$ from the Upper Villányian (MN 17) locality mentioned by Kormos (1930[1931] and 1934) - the only available fragment of skull (note the deformation of the specimen), $\mathrm{Da}$ - ventral view, $\mathrm{Db}$ - anterior view. Scale bars: grey for teeth, white for mandibles and skull.

Included species. - Hypolagus apachensis Gazin, 1930; H. arizonensis Downey, 1962; H. brachygnathus (Kormos, 1930); H. browni (Hay, 1921); H. edensis Frick, 1921; H. fontinalis Dawson, 1958; H. furlongi Gazin, 1934;
H. gidleyi White, 1987; H. giganteus (Brown, 1908); H. igromovi Gureev, 1964; H. limnetus Gazin, 1934; H. mexicanitx Miller \& Corranza-Castańeda, 1982; H. multiplicatus (Erbajeva in Bazarov et al., 1976); H. oregonensis Shotwell, 
1956; H. parviplicatus Dawson, 1958; H. peregrinus Fladerer \& Fiore, 2003; H. petenyii Čermák \& Fladerer sp. nov.; H. regalis Hibbard, 1939; H. ringoldensis Gustafson, 1978; H. schreuderae Teilhard de Chardin, 1940; H. tedfordi White 1987; H. transbaicalicus (Erbajeva in Bazarov et al., 1976); H. vetus (Kellogg, 1910); H. voorhiesi White, 1987.

\section{Hypolagus petenyii Čermák \& Fladerer sp. nov.}

Remark. - Florian A. Fladerer who first distinguished two forms of Hypolagus in Central Europe is, with his agreement, the co-author of this species description.

Holotype. - The left p3 (No. Ob/4757; Fig. 6B) deposited in the collections of MAFI (collected by Kormos in 1917).

Type locality and age. - Beremend, Hungary; the Early Villányian, MN 16 (Kordos 1991 and personal communication).

Description of the holotype. - In the holotype (Fig. 6B), (1) the anteroconid is short and triangular (morphotype I), (2) the buccal part of the hypoconid possesses a clear edged-margin ("beremendensis-Kante [edge]" sensu Fladerer 1987; morphotype "a"), and (3) the hypoflexid is simple with uncrenulated enamel, in its interior part exten$\mathrm{ded} /$ bent with a thickened enamel wall (morphotype D). The measurements of the holotype are as follows: $\mathrm{L}=3.46$, $\mathrm{W}=3.32$ and $\mathrm{l}=1.29$.

Diagnosis. - A small sized leporid characterized by the combination of discriminant features that include - a short and triangular p3 anteroconid (morphotype I), an edgedmargin on the buccal part of the p3 hypoconid ("beremendensis-Kante [edge]" sensu Fladerer 1987; morphotype "a"), and a rounded P2 hypercone without hypoflexus (morphotype I), (sensu Fladerer 1987 and Fladerer \& Reiner 1996); supplemented by discriminant features described by Fostowicz-Frelik (2007a, p. 551) in "Emended diagnosis" for the less advanced taxonomic taxon referred to as "Hypolagus beremendensis (Kormos, 1930)" [the nomeclatural status is discussed above].

Differential diagnosis. - Hypolagus petenyii sp. nov. differs from $H$. igromovi in its taller mandibular body, shorter mandibular diastema and alveolar length of p3-m3; and uniformly high rate of less elongated and more triangular p3 with edged-margin of the hypoconid (i.e., p3 with morphotypes I and "a"). It differs from $H$. brachygnathus in its smaller size; mandibular diastema - shorter than the lower alveolar p3-m3 length; shorter and more triangular p3 anteroconid (morphotype I), the edged-margin of the buccal part of p3 hypoconid (morphotype "a"), rounded P2 hypercone without hypoflexus ( morphotype I); and more gracile postcranial skeleton with distinctively less cursorially structured limbs. It differs from $H$. peregrinus in its taller mandibular body, longer maxillar and mandibular diastemas; more triangular $\mathrm{p} 3$ with edged-margin of the hypoconid and absence of advanced morphotypes of $\mathrm{p} 3$ and $\mathrm{P} 2$ (i.e., IV and V in p3; and IV in P2); and less cursorially structured limbs (compare with Averianov 1996; Fladerer 1984, 1987; Fladerer \& Reiner 1996; Fladerer \& Fiore 2003; Fostowicz-Frelik 2003, 2007a, b).

Etymology. - In honour of Salamon János Petényi, a founder of scientific mammalogy in Hungary and the first discoverer of this fossil taxon who, by a coincidence of inauspicious circumstances, did not become the author of the species description.

Synoptic survey of bibliography and occurrences of the species. - This overview is restricted to Central Europe and some adjacent regions. Bibliographic references to occurrences of the species are grouped according to names/combinations used by particular authors. The names/combinations are arranged chronologically, based on their first usage in context of this species. Major and/or more detailed studies on Hypolagus are specified as follows: ( $\mathrm{t}$ - - a detailed taxonomic study, or revision ( $\mathrm{n}$ ) - a study with nomenclatural revision/results, (d) - a valid description of new taxa, or (b) - a bibliographic review.

Lepus beremendensis Petényi. - Koch (1900), p. 544 [nomen nudum] (from Beremend [sensu Petényi 1864]).

Lepus (sp?). - [ex parte] Kormos (1911), p. 187 (from Beremend and Csarnóta [locality "a"sensu Kormos 1920]); Kormos (1920), p. 451 (Csarnóta [locality "a"]).

Lepus (Oryctolagus?) seu Lepus (Oryctolagus?) sp. - Kormos (1920), pp. 459, 461, 464, from Beremend 1-3, [?]4 and Csarnóta [locality "b" sensu Kormos 1920].

Lepus brachygnathus n. sp. - [?ex parte] (d) Kormos (1930), p. 46, from Beremend [?]1 - i.e. remains figured in Pl. II of Petényi (1864).

Hypolagus brachygnathus Kormos 1934 seu Hypolagus brachygnathus Kormos seu Hypolagus brachygnathus Korm. seu Hypolagus brachygnathus. - [?]Heller (1936), p. 137 (from Gundersheim sensu Heller 1936); [ex parte] Kormos (1937a), pp. 1088-1089 (from Beremend and Csarnóta); [ex parte] Kormos (1937b), p. 320 (from Beremend and Csarnóta); [ex parte] (t) Kowalski (1958a), pp. 3, 5, 18 (from Kadzielnia, Csarnóta 1, 2, Beremend 1, 4, 5 and Gundersheim); [ex parte] Mossoczy (1959), p. 132 (from Rębielice Królewskie); Kowalski (1961), p. 159 (from Węże [1]); [ex parte] Kowalski (1964), pp. 78, 85 (from Węże 1, Podlesice, Rębielice Królewskie and Kadzielnia); (t) Sulimski (1964), p. 153 (from Węże 1, Podlesice, Rębielice Królewskie, Ivanovce, Csarnóta-2 and Gundershein); [ex parte] Sych (1964), pp. 592-594 (from Węże 1, Rębielice 
Królewskie 1 and Kadzielnia); [ex parte] (t, n) Sych (1965), p. 4 (from Beremend 1-4, Csarnóta, [?]Gundersheim [sensu Heller 1936], Węże 1, Rębielice Królewskie 1 and Kadzielnia); Sych (1967a), p. 20 (from Rębielice Królewskie 1 and Kadzielnia); Sych (1966), pp. 41, 43, 45, 46, 49-52 (from Rębielice Królewskie and Kadzielnia); Daxner \& Fejfar (1967), p. 50 (from Węże 1 and Rębielice Królewskie); Sych (1967b), p. 28 (from Węże 1); Kowalski (1974), p. 198 (from Węże 1, Rębielice Królewskie and Kadzielnia); [ex parte] Tobien (1974), pp. 261-263 (from [?]Gundersheim; followed Heller 1936); Kowalski (1975), p. 100 (from Rębielice Królewskie); (b) Kowalski (1977), p. 99 (from Węże 1); [ex parte] Sych (1980), pp. 62, 63 (from Węże 1, Rębielice Królewskie 2, Zamkowa Dolna Cave and Kadzielnia); Tobien (1980), p. 212 (from [?]Gundersheim; followed Heller 1936); Czyżewska (1985), p. 4 (from Węże 1); Fejfar \& Heinrich (1985), p. 221 (from Ivanovce and Hajnáčka); Radulescu \& Samson (1985), p. 87 (from Debren 2); Fejfar et al. (1990), p. 52 (from Hajnáčka I); Radulesco \& Samson (2001), p. 288 (from Debren 2); Sabol (2001), p. 279 (from Hajnáčka); Sabol (2003), p. 600 (from Hajnáčka); Sabol et al. (2004), p. 80 (from Ivanovce and Hajnáčka; followed Fejfar \& Heinrich 1985); Sabol et al. (2005), p. 8 (from Hajnáčka); Sabol et al. (2006), pp. 269, 270 (from Hajnáčka).

Pliolagus beremendensis Kormos seu Pliolagus beremendensis (Kormos) seu Pliolagus beremendensis Korm. - [ex parte] Kormos (1937a), pp. 1088-1089 (from Beremend and Csarnóta); [ex parte] Kormos (1937b), pp. 297, 320 (from Beremend and Csarnóta); [ex parte] (b, n) Kretzoi (1956b), pp. 39, 46, 162, 169 (from [?]Beremend 4 and [?]Csarnóta 1); [ex parte] (t) Kowalski (1958a), p. 5 [followed Kretzoi (1956b), see above]; (n) Kretzoi (1962), pp. 348-349 (from Csarnóta [?]1 and 2).

Lagotherium beremendense (Petényi). - Kretzoi (1955), p. 90 (from Csarnóta); [ex parte] Kretzoi (1956a), p. 82 (from Beremend 5); [ex parte] (b, n) Kretzoi (1956b), pp. 32, 37, 39, 41, 46, 47, 154, 160, 162, 164, 169, 170, 263 (Beremend 1-4 [?ex parte], 5, Csarnóta [?]1, and 2); Sulimski (1962), p. 221 (from Węże 1, 2 and Kadzielnia); (b) Jánossy (1986), p. 26 (from Beremend 5; followed Kretzoi 1956b).

Pliolagus cf. tothi Kretzoi, 1941. - (t) Kowalski (1958a), p. 22 (from Kadzielnia).

Hypolagus sp. - Fejfar (1961b), p. 117 (from Ivanovce and Hajnáčka); Fejfar (1961c), p. 263 (from Ivanovce); Fejfar (1961d), pp. 276-279 (from Hajnáčka and Ivanovce); Fejfar (1964b), pp. 53-55 (from Hajnáčka); Berzi (1967), pp. 148, 149 (from Cascina Arondelli); Głazek et al. (1976), p. 451 (from [?]Draby 1); Głazek et al. (1977), p. 49 (from [?]Draby 1); Ložek \& Horáček (1992), p. 52 (from Hostovce 2); Čermák et al. (2007), p. 61 (from Měňany 3); Čermák et al. (2008), p. 99 (from Hostovce 2 and Měňany 3).

Hypolagus beremendensis (Petényi, 1864) seu Hypolagus beremendensis (Petényi) seu "Hypolagus beremendensis Petényi”. - (n) Kretzoi (1962), pp. 348-349 (from Csarnóta [?]1, 2); Jánossy (1973), p. 103 (from Osztramos 7); Tobien in Boenigk et al. (1977), p. 66 (from Wölfersheim); [ex parte] Jánossy \& Kordos (1977), p. 48 (from Osztramos 7); Jánossy (1978), p. 69 (from Osztramos 7); [ex parte] (b) Jánossy (1986), pp. 21, 26, 28, 30 (from Csarnóta 2, Beremend 1-3 [?ex parte], 11 and
Osztramos 7); Jánossy (1987), p. 91 (from Beremend 15); [ex parte] (t, n) Fladerer (1987), pp. 130, 135 (from Beremend 1, 5, Węże, Ivanovce, Hajnáčka, Deutsch-Altenburg 9, 20, 21 and [?]Csarnóta 1, 3); [ex parte] (b) Wolsan (1989), pp. 146, 147, Table 1 (from Węże 1 and 2, Mokra 1 (Poland), [?]Draby 1, Raciszyn 1, Rębielice Królewskie 1 and 2, Zamkowa Dolna Cave, Kielniki 3B and Kadzielnia 1); [ex parte] (b) Maul (1990), p. 167 (from Kadzielnia); [ex parte] (b) Wolsan (1990), pp. 273-275 (from Kadzielnia 1 and Węże 1); [ex parte] (t, n) Fladerer \& Reiner (1996), p. 149 (from Kadzielnia 1, Deutsch-Altenburg 9, 20, 21, Rębielice Królewskie 1, Hajnáčka 1, Zamkowa Dolna Cave, Węże 1, Ivanovce 1 and [?]Csarnóta 1, 3); [ex parte] (b) Frank \& Rabeder (1997), pp. 253, 257 (from Deutsch-Altenburg 9, 20 and 21); Dahlmann (2001), p. 95 [from Wölfersheim, followed Tobien in Boenigk et al. (1977)]; [ex parte] (t, n) Fladerer \& Fiore 2003, pp. 43, 54 (from Beremend 1, Csarnóta, Deutsch-Altenburg 9, 20, 21, Ivanovce, Zamkowa Dolna Cave, Kadzielnia 1, Rębielice Królewskie 1, Węże, [?]Thames Valley and [?]Cascina Arondelli); [ex parte] (t, n, b) Fostowicz-Frelik (2003), pp. 198, 210 (from Węże 1, 2, Rębielice Królewskie 1, 2, Kadzielnia, Zamkowa Dolna Cave, Ivanovce 1, [?]Csarnóta 1, 3 and Osztramos 7); [?ex parte] (t) Popov (2004), pp. 443-444 (from Muselievo).

Hypolagus beremendensis (Petényi, 1900). - Mais \& Rabeder (1977a), p. 3 (from Deutsch-Altenburg 9); Mais \& Rabeder (1977b), p. 85 (from Deutsch-Altenburg 20).

Hylopagus brachygnathus Kormos [= lapsus calami]. - (b) Kowalski (1977), p. 98 (followed [?]Kowalski 1958a [ex parte], Sulimski 1964, Sych 1964 [ex parte], [?]1965 [ex parte], and 1967a, b; see above).

Hypolagus beremendensis (Kormos, 1930). - (t, n) Fostowicz-Frelik (2007a), pp. 541-590 (from Kadzielnia 1, Kielniki 3B, Mokra 1 (Poland), Przymiłowice 3A, Raciszyn 1, Rębielice Królewskie 1 and 2, Węże 1 and 2 and Zamkowa Dolna Cave); (t) Fostowicz-Frelik (2007b), pp. 447-476 (from Węże 1, Rębielice Królewskie 1 and 2 and Kadzielnia 1); (b) Maul (2007), pp. 215-233 (from Kadzielnia 1, Przymiłowice 3A, Rębielice Królewskie 1 and 2, Węże 1 and 2 and Zamkowa Dolna Cave; followed Fostowicz-Frelik 2007a).

Updated occurrences in the Czech and Slovak Republics. - Hajnáčka I (SK), Hostovce 2 (SK), Ivanovce 1 (SK), Měňany $3(\mathrm{CZ})$; the positions of localities are shown in Fig. 1.

Stratigraphic and geographic distribution. - The provable occurrences from the Late Ruscinian (MN 15b) to Late Villányian (MN 17) in Europe; the core range in Central Europe.

\section{Hypolagus brachygnathus (Kormos, 1930)}

1934 Pliolagus beremendensis; Kormos, pp. 66/73, fig. 1s-t. 1934 Hypolagus brachygnathus; Kormos, pp. 69/75. 1941 Pliolagus tothi; Kretzoi, pp. 250/322, fig. 6/1-2. 
Neotype. - The neotype, designated in this paper (see above for details), is a fragment of the left mandible with i1 and p3-m3 (No. Ob/3689; Fig. 6Aa-Ad) deposited in the collections of MAFI (collected by Kormos in 1930).

Type locality and age. - Villány 3, Hungary; the Late Villányian, MN 17.

Diagnosis. - Provided by Fostowicz-Frelik (2007a, p. 552) in "Emended diagnosis" for the more advanced taxonomic taxon referred to as "Hypolagus brachygnathus (Petényi, 1864)“" [the nomeclature is discussed above].

Differential diagnosis. - Hypolagus brachygnathus differs from $H$. igromovi in its taller mandibular body, shorter mandibular diastema and alveolar length of p3-m3; wider p3 anteroconid, and longer p3 protoflexid. It differs from $H$. petenyii sp. nov. in its larger size; mandibular diastema - nearly equal to the lower alveolar p3-m3 length ; increased variability of p3 enamel pattern, presence of the more advanced morphotypes of $\mathrm{p} 3$ (i.e., morphotypes II-V and "b"-"e") and P2 (i.e., morphotypes IV-V and B); and more robust and massive postcranial skeleton with distinctively more cursorially structured limbs (more compared with $H$. peregrinus). It differs from $H$. peregrinus in its taller mandibular body, longer mandibular diastema; less advanced p3 with lower grade of re-entrance development in the anteroconid; and more cursorially structured limbs (compare with Averianov 1996; Fladerer 1984, 1987; Fladerer \& Reiner 1996; Fladerer \& Fiore 2003; Fostowicz-Frelik 2003, 2007a, b).

Synoptic survey of bibliography and occurrences of the species. - See the same chapter above for the explanation.

Lepus (sp?). - [ex parte] Kormos (1911), p. 187 (from Nagyharsányhegy [?ex parte]).

Lepus (europaeus Pall.?). - [?ex parte] Kormos (1914b), pp. 502, 565 (from Püspökfürdő [= Betfia] - locality IV [sensu Kormos 1914b]).

[?] Oryctolagus cuniculus L. seu Oryctolagus cuniculus. Kormos (1914b), pp. 501, 504, 562, 566 (from Püspökfürdő [= Betfia] - locality II and "Höhlenausfüllung").

Lepus europaeus Pall. - Heller (1930), p. 269 (from Sackdillinger Höhle).

Oryctolagus beremendensis n. sp. seu Oryctolagus beremendensis. - (d) Kormos (1930), p. 46 [nomen nudum] (from Püspökfürdô [= Betfia] - localities II and "Höhlenausfüllung" [sensu Kormos 1914b]); Kormos [1930 (1931)], p. 237 [nomen nudum] (from Villány 3).

Lepus brachygnathus n. sp. seu Lepus brachygnathus. - [?ex parte] Kormos (1930), p. 46 (from Püspökfürdó [= Betfia] - locality IV [sensu Kormos 1914b]); Kormos [1930 (1931)], p. 237 (from Villány 3).

Pliolagus beremendensis n. gen. n. sp. seu Pliolagus bere- mendensis Kormos seu Pliolagus beremendensis (Kormos) seu Pliolagus beremendensis.- (t, d) Kormos (1934), pp. 66, 77 (from Villány-Kalkberg [= Villány 3]); Schreuder 1937, p. 227 [followed Kormos 1934]; [ex parte] Kormos (1937a), p. 1090 (from Villány-Kalkberg); [ex parte] Kormos (1937b), pp. 297, 320 (from Villány-Kalkberg); (n, d) Kretzoi (1941b), pp. 250, 251, 322 (from Villány-Kalkberg); [ex parte] (b, n) Kretzoi (1956b), pp. 61, 184 (from Villány 3); [ex parte] (t) Kowalski (1958a), p. 5 [followed Kretzoi 1956b]; Daxner \& Fejfar (1967), p. 50 (from Villány-Kalkberg); (b) Jánossy (1986), p. 33 (from Villány 3).

Hypolagus brachygnathus n. sp. seu Hypolagus brachygnathus Kormos, 1934 seu Hypolagus brachygnathus Kormos seu Hypolagus brachygnathus Korm. seu Hypolagus brachygnathus seu "Hypolagus brachygnathus Kormos". - (t, d) Kormos (1934), pp. 69, 74-77 (from Nagyharsányhegy, Villány 3, Beremend [?]4 [partially; cf. Kretzoi 1956b], Csarnóta - unspecified/unknown locality and age [sensu Kormos 1934, pp. 68, 77; fig. 2f], Sackdillinger Höhle and Püspökfürdő); Schreuder (1937), pp. 225-229, Pl. II (from Tegelen); [ex parte] Kormos (1937a), pp. 1090, 1091 (from Villány-Kalkberg and Nagyharsányhegy); [ex parte] Kormos (1937b), p. 320 (from Villány-Kalkberg, Nagyharsányhegy and Püspökfürdó); [ex parte] (t) Kowalski (1958a), p. 5 (from Villány 3, 5, 6, 7, 8, Nagyharsányhegy 2, 4, Püspökfürdő, Podumci and Tegelen); Kowalski (1958b), pp. 6, 13 (from Podumci); [ex parte] Mossoczy (1959), p. 133 (from Kamyk); Fejfar (1961d), p. 279 (from Chlum 6); Dehm (1962), pp. 52, 53, Pl. 6: 23 (from Schernfeld); Malez (1962), p. 314 (from Podumci); [ex parte] Kowalski (1964), pp. 78, 85 (from Kamyk); Sych (1964), pp. 592-594 (from Kamyk); [ex parte] (t, n) Sych (1965), p. 4 (from Nagyharsányhegy, Villány [the Early Pleistocene localities], Kislang, Betfia [sensu Kretzoi 1941b], Podumci, Tegelen, Sackdillinger Höhle, Schernfeld and Kamyk); Bolomey (1965), p. 80 (from [?] Pietriș); Malez (1968a), p. 152 (from Podumci); Malez (1968b), p. 206 (from Podumci); Malez (1969a), pp. 74, 75 (from Podumci); Malez (1969b), p. 321/1-6 (from Podumci; followed Kowalski 1958b); Terzea \& Jurcsák (1969), pp. 201-213 (from Betfia); Malez (1970), p. 210 (from Podumci); Malez (1971), pp. 66, 67 (from Podumci); Terzea (1973), p. 230 (from Betfia 13); [ex parte] Tobien (1974), pp. 261-263 (from Schernfeld; followed Dehm 1962); Koenigswald in Bartolomei et al. (1975), p. 400 (from Sackdillinger Höhle; followed Heller 1956); Terzea \& Jurcsák (1976), p. 176 (from Betfia 13); Jánossy \& Kordos (1977), p. 45 (from Osztramos 3); [ex parte] Sych (1980), p. 63 (from Kamyk); Fejfar \& Horáček (1983), p. 127 (from Holštejn); Radulesco \& Samson (1986), p. 161 (from Izvoru 2); (t, n) Fladerer (1987), pp. 130, 131, 136 (from Villány 3, Kövesvárad, Deutsch-Altenburg 4B, 2C1, Včeláre 4E, Chlum 6 and Kamyk); Radulesco \& Samson (1990), p. 227 (from [?] Pietriș); Terzea (1996), p. 534 (from Betfia 7, 9, 10, 11 and 13); Paunovic \& Rabeder (1996), p. 82 (from Podumci); Hír \& Venczel (1997), p. 113 (from Betfia 9/B); Averianov \& Tesakov (1998), p. 92 (from the Late Pliocene localities of Europe provided by Fladerer (1987), morphotypes III/E, V/A, V/E); (t) Chaline et al. (2000), pp. 93, 95-100, 103 (from [?] Montoussé-5); (t, n) Fladerer \& Fiore (2003), p. 43 (from Deutsch-Altenburg 4B, 2C, 22, Holštejn, Chlum 6, Mladeč 3, Stránská skála [(?) Cave - test pit 2] and Kamyk); 
(b) Maul (2007), pp. 215-233 (from Villány 5; followed Sych 1965).

Pliolagus tothi n. sp. seu Pliolagus tothi Kretzoi, 1941 seu Pliolagus tothi Kretzoi. - (n, d) Kretzoi (1941b), pp. 250, 251 [p. 250 "Pliogalus tóthi n. sp." = lapsus calami], pp. 322, 323 (from Betfia 5 [= Püspökfürdő]); (t) Kowalski (1958a), p. 5 (from Betfia [5]); (b) Maul (1990), p. 169 (from Betfia 5; followed Kretzoi 1941b).

Lagotherium brachygnathum (Kormos). - (n, d) Kretzoi (1941b), pp. 251-252, 323-324 (from Betfia 5).

[?] Lagotherium sp. (?n.) indet seu Lagotherium sp. - (n) Kretzoi (1954), pp. 222, 248 (from Kisláng); (b) Jánossy (1986), p. 44 (from Kisláng; followed Kretzoi 1954).

[?] Oryctolagus (?) sp. indet. - (n) Kretzoi (1954), pp. 222, 248 (from Kisláng).

Lagotherium beremendense (Petényi) seu Lagotherium beremendensis (Petényi). - [ex parte] Kretzoi (1956a), pp. 84-85 (from Villány 5 and 8/11); [ex parte] (n, b) Kretzoi (1956b), pp. 37, 39, 52, 56, 61, 65, 70, 72, 75, 78, 160, 162, 176, 179, 184, 188, 193, 195, 198, 201, 263 (from Beremend 1-4 [?ex parte], Nagyharsányhegy 2, 4, Villány 3, [?]4, [?]5, 6, 7, 8/12b, 8/11); [ex parte] (b) Jánossy (1986), pp. 28, 38, 48, 54 (from Beremend 1-3[?ex parte], Villány [?]5, 6, Nagyharsányhegy 2 and 4; followed Kretzoi 1956b).

Lagotherium (Hypolagus) brachygnathum (Korm.). - Heller (1956), p. 527 (from Sackdillinger Höhle).

Hypolagus sp. seu Hypolagus. - Malez (1959), p. 14 (from [?] Marjan); Malez (1960), p. 116 (from [?] Marjan); Malez (1961), p. 15 (from [?] Marjan); Malez (1962), p. 315 (from [?] Marjan); Kretzoi (1965), p. 621 (from [?] Marjan; followed Malez 1959); Malez (1969b), p. 321/1-6 (from [?] Marjan); Malez (1970), p. 208 (from [?] Marjan); Kowalski (1975), p. 101 (from Kielniky); Popov (1988), p. 201 (from Varbeshnitsa); [ex parte] Maul (1990), pp. 164-169 (from [?] Marjan, Včeláre 5 and Zalesiaki 1A).

Hypolagus beremendensis (Petényi, 1864) seu Hypolagus beremendensis (Petényi) seu Hypolagus beremendensis Petényi seu Hypolagus beremendensis seu "Hypolagus beremendense Petényi”. - Fejfar (1961a), pp. 171, 172 (from Chlum 6 and Koliňany); Fejfar (1961b), p. 117 (from Chlum 6); (n) Jánossy (1963), pp. 111, 125, 132 (from Kövesvárad), [p. 125 “Lepus brachygnathus Petényi” = lapsus calami]; Fejfar (1964a), p. 351 (from Chlum 4); Ložek (1964), p. 67 (from Chlum 6); Kretzoi (1965), pp. 614, 618, 619, 621, 622, 623, 627 (from Kövesvárad [followed Jánossy 1963], Betfia 2, Podumci, Nagyharsányhegy 2, 4, Villány 6, 8/12, 8/11 and Sackdillinger Höhle); Musil (1965), pp. 85, 83, 103 (from Stránská skála); Musil (1966), pp. 135, 142 (from Holštejn); Musil \& Valoch (1968), pp. 534-539 (from Stránská skála); Tobien (1972), p. 145 (from Stránská skála); Musil (1974), p. 88 (from Lažánky); Fejfar in Bartolomei et al. (1975), p. 409 (from Chlum 4, 6 and Holštejn); Jánossy in Bartolomei et al. (1975), p. 427 (from Kövesvárad); [ex parte] Jánossy \& Kordos (1977), p. 43 (from Osztramos 2 and 8); Fejfar \& Horáček (1983), p. 128 (from Chlum 6); [ex parte] (t, n, d) Fladerer (1984) (from Deutsch-Altenburg 4B and 2C); Malez \& Rabeder (1984), p. 451 (from Podumci); [ex parte] (b) Jánossy (1986), pp. 33, 36, 50, 52, 65 (Villány 3, Osztramos 2, 3, 8 [fol- lowed Kretzoi (1956b)] and Kövesvárad); [ex parte] (t, n) Fladerer (1987), p. 130 (from Villány-Kalkberg and Betfia; followed Sulimski 1964 and Sych 1965); [ex parte] (b) Wolsan (1989), pp. 146, 147, Table 1 (from Kamyk, Kielniki 3A and Zalesiaki 1A); Jánossy \& Topál (1990), p. 18 (from Újlaki-hegy); [ex parte] (b) Maul (1990), pp. 164-169 (from Podumci 1, Courterolles, Les Valerots, Kamyk, Kielniky 3A, Deutsch-Altenburg 2C, 2D/E, 4B, 30A, Chlum 4, 6, Holštejn, Stránská skála, Kövesvárad, Nagyharsányhegy 2, 4, Osztramos 2, 8, Villány 5, 6, 8/9-12 and Betfia 5, 13); [ex parte] (b) Wolsan (1990), pp. 273-275 (from Kamyk, Kielniki 3A and Zalesiaki 1A/13); Jánossy \& Krolopp (1994), pp. 416, 428 (from Győrújfalu); [ex parte] (t, n) Fladerer \& Reiner (1996), p. 149 (from [?]Stránská skála 2 (Cave), Mladeč 3, Kövesvárad, Stránská skála 1, Mladeč 1, Holštejn, Deutsch-Altenburg 4B, 2C1, 22, 30A, Včeláre 4, Kamyk, Villány 3 and Včeláre 5); Jánossy (1996), pp. 94, 99 (from Beremend 16 and 17); [ex parte] (b) Frank \& Rabeder (1997), p. 246 (from Deutsch-Altenburg 30A, 4B, 2C1, 2 and 2D/E); Koenigswald \& Heinrich (1999), p. 77 (from Chlum 6); (b) Averianov 2001, p. 86 (from Schernfeld, Villány 3, Betfia 13, Chlum 6, Deutsch-Altenburg [the Early Biharian sites], Chishmikioy, Cherevichnoe [unspecified locality], Podumci, Betfia 5, Varbeshnitsa and [?] Emirkaya-2); Musil (2001), p. 30 (from Holštejn); [ex parte] (t, n) Fladerer \& Fiore (2003), p. 54 (from Tegelen); [ex parte] (t, n, b) Fostowicz-Frelik (2003), pp. 198, 210 (from Kamyk, Chlum [?6], Holštejn, Stránská skála, Stránská skála [?Cave], Mladeč 3, Villány 3, Deutsch-Altenburg 4B, 2C1 and Betfia); Musil \& Valoch (2005), p. 83 (from Stránská skála); (b) Maul (2007), pp. 215-233 (from Deutsch-Altenburg 4B, 2C, 30; followed Fladerer 1984).

Hypolagus (Lagotherium) beremendense Petényi. - Jánossy (1972), p. 166 (from Osztramos 8).

Pliolagus cf. beremendensis Kormos, 1934. - (t) Shushpanov (1977), p. 59 (from Chishmikioy); (b) Maul (1990), p. 169 (from Chishmikioy).

Hylopagus brachygnathus Kormos [= lapsus calami]. - (b) Kowalski (1977), p. 98 (followed [?]Kowalski 1958a [ex parte], Sych 1964 [ex parte], [?]1965 [ex parte]; see above).

Hypolagus brachygnathus (Petényi, 1864). - (t, n) Fostowicz-Frelik (2007a), pp. 541-590 (from Kamyk, Kielniky 3A, Zalesiaki 1 and Żabia Cave); (t) Fostowicz-Frelik (2007b), p. 470; (b) Maul (2007), pp. 215-233 (from Untermaßfeld; from Kamyk, Kielniky 3A, Zalesiaki 1 and Żabia Cave - followed Fostowicz-Frelik 2007a).

Updated occurrences in the Czech and Slovak Republics. Chlum 4, 6, 8 (CZ), Gombasek (SK), Holštejn (CZ), Lažánky 2 (CZ), Mladeč 1, 3 - point [7/10] (CZ), Stránská skála (CZ), Včeláre 4E, 5, 6/8, 10B (SK). The positions of localities are shown in Fig. 1.

Considering the available combination of all the above mentioned facts (i.e. - the size of sample; the age (or uncertain age) of localities; or relatively less advanced morphotypes than in typical representatives of the Biharian $\mathrm{H}$. brachygnathus), the specimens from Měňany 2 (CZ), Mokrá 1 
(CZ), Koliňany 1 (SK) and Včeláre 3/B3, 7 (SK) are tentatively assigned here to Hypolagus cf. brachygnathus.

Stratigraphic and geographic distribution. - The provable occurrences from the Late Villányian (MN 17) to Latest Biharian (Q2) in Europe; the core range in Central Europe and Northern Balkans.

\section{Phylogeny and paleobiogeography}

At the present state of knowledge, the phylogenetic relationship between particular Eurasian taxa of Hypolagus is still very incomplete. Hypolagus, originated in North America, migrated to Asia probably during the Late Miocene (Turolian, probably before MN 13) over the Beringia land bridge (Qiu 1987, Averianov 2001). One of the earliest Asian fossil records of the genus (a single p3 assigned to Hypolagus sp. [indet.]) comes from the Chinese (Inner Mongolia) locality Harr Obo 2 correlated as approximately at the Miocene-Pliocene boundary, MN 13/14 (Qiu 1987, Cai 1989, Averianov 1996). The oldest representatives of the genus in Europe, probably in the Old World as well, are remains of Hypolagus igromovi Gureev, 1964 from the Late Turolian (MN 13) locality Rasdorskaya, Rostov Region, Southern European Russia (Gureev 1964 and Averianov 1996). Other finds with $H$. igromovi affinities are also reported (compare with Averianov 1996) from the Ruscinian (MN 14-15) localities Kosyakino, Northern Caucasus (Averianov \& Tesakov 1998), Musait, Moldova (David \& Shushpanov 1986), Ajagus, Kazakhstan (Erbajeva 1982) and possibly from the Early Villányian (?MN 16) locality Zolotushka, Altai Region, Russia (Averianov 1996).

When and from which ancestor the more primitive Hypolagus species of Central Europe, H. petenyii sp. nov., arose is largely unknown. The first clear evidence of the species in the studied region comes from the Late Ruscinian localities (e.g. from Węże 1 or Ivanovce 1) while the taxonomic status of fragmentary leporid remains from the Early Ruscinian localities Osztramos 1 (Jánossy 1986) and Podlesice (Kowalski 1964, Sych 1980) is still unclear. Fladerer \& Fiore (2003) tentatively proposed "less specialized [representatives of] H. igromovi" as a possible ancestor of $H$. petenyii sp. nov. This hypothesis seems to be unlikely, because $H$. igromovi, already known since the Late Turolian, MN 13 (see above), exhibits much more advanced p3 structures, than in the Late Ruscinian-Late Villányian $H$. petenyii sp. nov. We cannot exclude that the European range of $H$. petenyii sp. nov. originated from one of independent migration events of Hypolagus from Asia to Europe during the Neogene; i.e., the first possible dispersal during the Late Turolian to the Don Region (= migration of $H$. igromovi), the second one during the Late or Early Ruscinian to Central Europe (= migration of $H$. petenyii sp. nov.), compare with e.g. Rössner \& Heissig 1999, Matthee et al. 2004, Koufos et al. 2005, etc. The relationships of the European taxa to the Villányan - Biharian (?Dachaian-Nihewanian) Hypolagus multiplicatus (Erbajeva in Bazarov et al., 1976) and H. transbaicalicus (Erbajeva in Bazarov et al., 1976), both from the Transbaikalian region, and $H$. schreuderae Teilhard de Chardin, 1940 from China, remain obscure (Teilhard de Chardin 1940, Bazarov et al. 1976, Qiu 1987, Erbajeva 1996, Erbajeva \& Alexeeva 2000, Fostowicz-Frelik 2003). Moreover, taking into account the large intraspecific and ontogenetic variability within Hypolagus paleopopulations, the coexistence and separation of the small and large, morphologically very similar forms in the Transbaikalian region (i.e., H. multiplicatus and $H$. transbaicalicus) appears questionable; thus the status and relationship of these species needs further revision (compare also with Fostowicz-Frelik 2003).

Analyzing the available literature, the phylogenetic relationship of the relatively advanced, large and cursorial $H$. brachygnathus (Kormos, 1930) of Central Europe to other relevant species is still poorly known. Although limited in terms of fossil record availability, it is possible to suggest three alternative hypotheses: (1) H. brachygnathus (Kormos, 1930) originated from $H$. petenyii sp. nov. in the Late Villányian and form one evolutionary lineage (Fladerer 1987, Fladerer \& Reiner 1996, and Fladerer \& Fiore 2003); or (2) H. brachygnathus (Kormos, 1930) originated from H. igromovi Gureev, 1964 (an alternative possible evolutionary lineage) and invaded Central Europe from the Early Villányian (Fostowicz-Frelik 2003); or (3) H. brachygnathus (Kormos, 1930) in Central Europe is a result of one of the independent migration events (probably the third one; see above) of Hypolagus from Asia and has no connection with either $H$. petenyii sp. nov. or $H$. igromovi Gureev, 1964 . To avoid possible misunderstandings in the future, it is necessary to comment on certain taxonomical and nomenclatural inconsistencies in the tentative relevant hypothesis (here No. 2) proposed by Fostowicz-Frelik (2003). Despite, her acceptance (Fostowicz-Frelik 2003) of the taxonomic view of Fladerer \& Reiner (1996) i.e. the Pliocene $H$. b. beremendensis and Pleistocene $H$. b. brachygnathus are two chronosubspecies of a single clade, she proposed that the younger chronosubspecies, i.e. H. b. brachygnathus, is a direct descendant of $H$. igromovi. Her view resulted in the statement that " $\ldots H . b$. brachygnathus is derived from $\mathrm{H}$. igromovi, which was invading Europe since the Early Villányian (MN 16) and which gradually forced out $H$. beremendensis. ..." (Fostowicz-Frelik 2003, p. 211). This is in contradiction with the basic taxonomic concept of species monophyly (see e.g. Henning 1950, or less strict Simpson 1961, etc.). The "beremendensis-igromovi group" (sensu Fostowicz-Frelik 2003) actually concerns two independent 
species H. igromovi Gureev, 1964 and H. brachygnathus (Kormos, 1930) and it should rather be called the "igromovi-brachygnathus group". This morphological group can be looked upon as relevant because both the species actually share similar proportions and/or shapes of mandible and teeth, though it is not clear whether this is due to an actual relationship or parallel evolution. Overall, because of the limited data available, there is no conclusive evidence that could support any one of the above three tentative hypothesis, thus further material and studies are needed to test them.

Limited in terms of available fossil record, the precise distribution of $H$. petenyii sp. nov. and $H$. brachygnathus (Kormos, 1930) in the Late Villányian-Earliest Biharian of Central Europe is still poorly known; and this also effects their LAD and FAD, respectively (compare with Fladerer 1987, Fladerer \& Reiner 1996, Fladerer \& Fiore 2003 and Fostowicz-Frelik 2003, 2007a). The last well proven appearances of $H$. petenyii sp. nov. from Austria, Hungary and Slovakia are known from the Early Villányian (MN 16) localities Deutsch-Altenburg 9, 20, 21, Beremend 4 (part), Osztramos 7 and Hajnáčka I, while from Poland the species is reported by Fostowicz-Frelik (2007a) still from the Late Villányian (MN 17) localities Kadzielnia 1, Przymiłowice 3A (1 p3) and Kielniki 3B (2 p3s), or even from the Early Biharian (Q1) locality Kamyk (14 postcranial fragments vs. 2764 specimens of $H$. brachygnathus (Kormos, 1930); Fostowicz-Frelik 2007a). The first well proven appearances of $H$. brachygnathus (Kormos, 1930) are from the Late Villányian (MN17) locality Villány 3 (Hungary), tentatively from Koliňany 1, Včeláre 3/B3, 7 (all from Slovakia); while from Poland the species is reported by Fostowicz-Frelik (2007a) above the Villányan-Biharian boundary, from the locality Kamyk. The abundance of $H$. petenyii sp. nov. decreased extensively during the Late Villányian, most probably due to the spreading of $H$. brachygnathus (Kormos, 1930) in Central Europe. The enhancement of the cursorial adaptations of the latter (Sych 1965, Fladerer 1984, Fladerer \& Fiore 2003 and Fostowicz-Frelik 2007b) in an environment evolving towards more open habitats with the beginning of the Pleistocene, certainly increased selection for these qualities in H. brachygnathus (Kormos, 1930) and most probably gave way to increasing its abundance (Fladerer \& Reiner 1996). During the Biharian, the abundance of the latter species decreased as evidence of the sympatric Lepus taxa increased (Fladerer \& Reiner 1996). The presumably last Central European Hypolagus survived until the end of the Biharian; the youngest records are reported by Maul (2007) from Hungarian and Romanian localities (from "Faunal Group 4" sensu Maul 2007; compare also with Maul et al. 2007) Nagyharsányhegy 4, Villány 6, 7, 8 (Kretzoi 1956b), Kövesvárad (Jánossy 1963), Somssich-Hill 2 (Jánossy 1983) and Betfia 7/3a (Terzea 1996), and completed by
Chlum 4 (the Czech Republic) and Gombasek (Slovakia) in this paper.

Based on the stratigraphical assignment of Horáček \& Ložek (1984, 1988), the records of Hypolagus from Mladeč 3 - point [7/10] and Stránská skála [“2 (Cave)" or "cave - test pit 2" after Fladerer \& Reiner 1996 and/or Fladerer \& Fiore 2003] was considered by Fladerer \& Reiner (1996) and Fladerer \& Fiore (2003) as the last appearances of the genus in Central Europe (the view was held also by Fostowicz-Frelik 2003, 2007a). Nevertheless, both the records are apparently misinterpreted. The cave system of Mladeč is infilled with a very complicated series of sedimentary complexes and only a few of them provided a reliable paleontological record. The Hypolagus tooth was found at a site tentatively correlated by Horáček \& Ložek (1984) with the nearby series of Mladeč 3 which provided the Early Toringian (Q3) assemblage (I. Horáček, personal communication). At point [7/10], the record was very scarce and fragmentary and younger contaminations cannot also be excluded. The present author, with I. Horáček and J. Wagner, carried out (in 2007) an additional investigation of the site with the aim to collect a more sufficient number of fossils and refine its age; but no stratigraphically significant specimens were obtained. Thus, to date there are no data available to provide a proper age assignment of the Hypolagus specimen from Mladeč 3 - point [7/10]. Conclusions on the record from Stránská skála (one p3 of III/A/d - type) provided by Fladerer \& Reiner (1996, pp. 149,158 ) also seem to be confusing. Unfortunately, neither from Fladerer \& Reiner (1996) nor from the following work is it totally clear from which site in Stránská skála the particular Hypolagus specimen originates. In reality, the Stránská skála site ["2 (Cave)" or "cave - test pit 2" after Fladerer \& Reiner 1996 and/or Fladerer \& Fiore 2003] is not identical with the Q3 (Toringian) site mentioned by Horáček \& Ložek (1988, p. 68, No. 25) Horáček, personal communication. Most of the Stránská skála record, deposited in MMB, from where the specimen was reported, comes almost exclusively from the sites with Biharian or even older assemblages (compare e.g., Musil 1968). The present author did not find any Hypolagus specimen in the rich Toringian assemblage of Stránská skála - Cave. Thus, the statement about survival of Hypolagus until the Early Toringian (Q3 in Fladerer \& Reiner 1996, or Early Steinheimian in Fostowicz-Frelik 2003, 2007a) in Moravian refuges, established on such a poor and/or uncertain fossil record, seems to be premature. In short, in the Czech and Slovak Republics there are no reliable post-Biharian records of this genus, its LAD is in the Late Biharian locality Chlum 4 (= the $4^{\text {th }}$ cave; see Horáček 1979, Horáček 1982 and Horáček \& Ložek 1988 for details).

Among the possible causes of extinction, two competing tentative views are noteworthy; (1) The generally ac- 
cepted view of Hypolagus extinction as a result of direct competition with a new immigrant, open habitat Lepus (Sych 1965, Fladerer 1987, Fladerer \& Reiner 1996, Fladerer \& Fiore 2003 and Fostowicz-Frelik 2003, 2007a), (2) Maul (2007) presented an alternative hypothesis, preferred in this paper, interpreting the extinction as a result of climatic changes during the the Early Middle-Pleistocene. In his opinion, the long-term (from the Latest Villányian to Late Biharian) sympatric co-occurrence (Maul 1998) of Hypolagus brychygnathus (Kormos, 1930) with progressive adaptation to a cursorial habit and the early European Lepus, less adapted to a cursorial habit than modern Lepus (Fladerer 1984), does not support the former hypothesis.

\section{Summary}

In conclusion, the following results can be inferred and briefly summarized from the facts considered above:

(1) The name Hypolagus brachygnathus (Kormos, 1930), with neotype No. Ob/3689 designated in this paper, is regarded here as the oldest available name for the more advanced form known from the Late Villányian Late Biharian of Central Europe. The usage of the name Oryctolagus beremendensis in Kormos (1930) is regarded here as a nomen nudum. The nominal taxon of Hypolagus brachygnathus Kormos, 1934 is regarded here as a junior objective synonym (the same name-bearing type) and simultaneously as a junior secondary homonym of Hypolagus brachygnathus (Kormos, 1930). The nominal taxa of Pliolagus beremendensis Kormos, 1934 from the Late Villányian (MN 17) locality Villány 3 and Pliolagus tothi Kretzoi, 1941 from the Biharian (the Betfia stage) locality Betfia 5 are regarded here as a subjective junior synonyms of Hypolagus brachygnathus (Kormos, 1930).

(2) The gracile and less advanced form known from the Late Ruscinian - Late Villányian (?Earliest Biharian) of Central Europe is described here as Hypolagus petenyii Čermák \& Fladerer sp. nov. (type locality Beremend, Hungary; Early Villányian, MN 16).

(3) The present study confirmed the results of the morphodynamic analysis provided by Fladerer (1987) and Fladerer \& Reiner (1996); the increasing complexity of the premolar pattern over time in the Late Ruscinian Late Biharian populations from the localities of the Czech and Slovak Republics was proved. Based on the studied material, in accordance with Fladerer (1987) and Fladerer \& Reiner (1996), the most discriminating criterion proved to be morphology of the p3 anteroconid together with morphology of the buccal part of the hypoconid, associated with morphology of the P2 hypercone; (1) H. petenyii Čermák \& Fladerer sp. nov. is characterized by a combination of discriminant features that include - the domination of morphotypes I and "a" in p3, and I-II in P2, (2) H. brachygnathus (Kormos, 1930) by the domination of morphotypes II-V and "b"-"e" in p3, and III-V in P2.

(4) A record of Hypolagus was proved from twentytwo Plio-Pleistocene (Ruscinian-Biharian) localities of the Czech and Slovak Republics; from eight localities, the genus is reported or described for the first time. Hypolagus petenyii Čermák \& Fladerer sp. nov. is reported here from the Late Ruscinian - Early Villányian localities Hajnáčka I (SK), Hostovce 2 (SK), Ivanovce 1 (SK) and Měňany 3 (CZ). Hypolagus brachygnathus (Kormos, 1930) is reported here from the Biharian localities Chlum 4, 6, $8(\mathrm{CZ})$, Gombasek (SK), Holštejn (CZ), Lažánky 2 (CZ), Mladeč 1, 3 - point [7/10] (CZ), Stránská skála (CZ) and Včeláre 4E, 5, 6/8, 10B (SK). The material from Koliňany 1 (SK), Měňany 2 (CZ), Mokrá 1 (CZ) and Včeláre 3/B3, 7 (SK) is tentatively assigned here to Hypolagus cf. brachygnathus (Kormos, 1930).

\section{Acknowledgements}

First of all, I would like to express my warmest thanks to colleague Jan Wagner (Academy of Sciences of the Czech Republic in Prague) for inspiring discussion on the complex and largely obscure questions regarding Hypolagus nomenclature and for valuable suggestions on the manuscript. I wish to convey my sincere thanks to Oldřich Fejfar and Ivan Horáček (both from Charles University in Prague) for providing me with the fossil material in their care and for numerous valuable comments. I am indebted to László Kordos (Geological Institute of Hungary in Budapest), Mihály Gasparik (Hungarian Museum of Natural History in Budapest), Boris Ekrt (National Museum in Prague), Martina Roblíčková and Martina Galetová (both from The Moravian Museum in Brno), Burkart Engesser (Natural History Museum in Basel), and Yuriy Semenov and Dmitry Ivanoff (both from Natural History Museum in Kiev) for the access to the collections in their care. I am also indebted to József Pálfy (Hungarian Museum of Natural History in Budapest) for the inspiring discussion and information on the nomenclaturally important leporid material of Hungary. I am also very grateful to László Kordos, József Pálfy, Laci Hajnal (Charles University in Prague) and Lucia Šimková (JENA in Prague) for invaluable help with papers in Hungarian. Last but not least, I express thanks to the referees Lutz Maul (Forschungsinstitut und Naturmuseum Senckenberg - Forschungsstation für Quartärpaläontologie in Weimar) and Martin Sabol (Comenius University in Bratislava) for their critical reading and helpful comments on the manuscript. The study was supported by grant No. 205/09/0184 from the Grant Agency of the Czech Republic, by the Academic Project of the Institute of Geology in Prague No. AV0Z30130516, by grant No. IAA300130701 from the Grant Agency of the Academy of Sciences of the Czech Republic and by grant No. MK00002327201 from the Ministry of Culture of the Czech Republic. 


\section{References}

AVERIANOV, A.O. 1996. The Neogene rabbit Hypolagus igromovi Gureev, 1964 (Lagomorpha, Leporidae) from southern European Russia. Acta zoologica cracoviensia 39(1), 61-66.

AVERIANOV, A.O. 2001. Zaitseobraznye (Mammalia, Lagomorpha) pleistocena Evrazii. Paleontologicheskii Zhurnal 2, 84-92.

AVERIANOV, A.O. \& TESAKOV, A.S. 1997. Evolutionary trends in Mio-Pliocene Leporinae, based on Trischizolagus (Mammalia, Lagomorpha). Paläontologische Zeitschrift 71(1/2), $145-153$.

AVERIANOV, A.O. \& TeSAKOV, A.S. 1998. Zaitseobraznye (Mammalia, Lagomorpha) iz rannepliotsenogo mestonakhozhdeniya Kosyakino na Severnom Kavkaze. Paleontologicheskii Zhurnal 3, 91-96.

Bartolomei, G., Chaline, J., Fejfar, O., JÁnossy, D., JeAnNet, M., KeOnigswald, W. VON \& Kowalski, K. 1975. Pliomys lenki (Heller 1930) (Rodentia, Mammalia) en Europe. Acta zoologica cracoviensia 20(10), 394-467.

BAZAROV, D.B., ERBAJEVA, M.A. \& REZANOV, N.I. 1976. Geologiya i fauna opornykh razrezov antropogena Zapadnogo Zabaikal'ya. 148 pp. Nauka, Moscow.

BERZI, A. 1967. Lagomorphs from the type Villafranchian of Villafranca d'Asti (Italy). Committee Mediterraneana Neogene Stratigraphy, Proc. IV Session, Bologna 1967. Giornale di Geologia 2, 35(1), 1-14.

Boenigk, W., Brelie, G., BrunNaCker, K., KempF, E.K., Kočí, A., Schirmer, W., Stadler, G., Streit, R. \& ToBIEN, H. 1977. Jungtertiär und Quartär im HorloffGraben/Vogelsberg. Geologische Abhandlungen Hessen 74, $1-80$.

BolOMEY, A. 1965. Die Fauna zweier villafrankischer Fundstellen in Rumänien. Berichte der Geologischen Gesellschaft der DDR 10(1), 77-88.

CAI, B. 1989. Fossil lagomorphs from the Late Pliocene of Yangyuan and Yuxian, Hebei. Vertebrata Palasiatica 27(3), 170-181.

ČERMÁK, S. 2007. New finds of Ochotonoma csarnotana (Lagomorpha, Ochotonidae) from the Pliocene of Hungary: a new look on the species. Neues Jahrbuch für Geologie und Paläontologie, Abhandlungen 246(2), 247-256. DOI $10.1127 / 0077-7749 / 2007 / 0246-0247$

ČERMÁK, S., WAGNER, J., FEJFAR, O. \& HORÁČEK, I. 2007. New Pliocene localities with micromammals from the Czech Republic: a preliminary report. Fossil Record 10(1), 60-68. DOI 10.1002/mmng.200600019

ČERMÁK, S., WAGNER, J., FEJFAR, O. \& HORÁČEK, I. 2008. Updated record of the Pliocene mammalian assemblanges from the Czech and Slovak Republic. Volume of Abstracts, $6^{\text {th }}$ Meeting of European Association of Vertebrate Palaeontologists, 99.

Chaline, J., Erbajeva, M.A. \& Montuire, S. 2000. Upper Pliocene leporids (Mammalia, Lagomorpha) from Montoussé-5 (Hautes-Pyrénées, France). Neues Jahrbuch für Geologie und Paläontologie, Monatshefte 2000(2), 93-106.
CROIZET, J.B. \& JOBERT, A. 1828. Recherches sur les ossemens fossiles du département du Puy-de-Dôme. 226 pp. Adolphe Delahays, Paris.

CZYŻEWSKA, T. 1985. Natural Endocranial Casts of Hypolagus brachygnathus Kormos, 1934 (Leporidae, Lagomorpha) from Węże I near Działoszyn (Poland). Acta zoologica cracoviensia $29,3-12$.

DAHLMANN, T. 2001. Die Kleinsäuger der unter-pliozänen Fundstelle Wölfersheim in der Wetterau (Mammalia: Lipotyphla, Chiroptera, Rodentia). Courier Forschungsinstitut Senckenberg 227, 1-129.

DAVID, A.I. \& SHUSHPANOV, K.I. 1986. Ostatki mlekopitayushchikh iz srednepliotsenovykh mestonakhozhdenii u s. Musaid, 21-34. In NegOdaeV-NiKonov, K.N. (ed.) Pliocen-antropogenovaya fauna Dnestrovsko-Prutskogo mezhdurech'ya. Kishinev.

DAwson, M. 1958. Later Tertiary Leporidae of North America. University of Kansas Paleontological Contributions 6, 1-75.

DAXNER, G. \& FEJFAR, O. 1967. Über die gattung Alilepus Dice, 1931 und Pliopentalagus Gureev, 1964 (Lagomorpha, Mammalia). Annalen des Naturhistorischen Museums Wien $71,37-55$.

DEHM, R. 1962. Altpleistocäne Säugetiere von Schernfeld bei Eichstätt in Bayern. Mitteilungen der Bayerischen Staatssammlung für Paläontologie und historishe Geologie 2, $17-61$.

DICE, L.R. 1929. The phylogeny of the Leporidae, with description of a new genus. Journal of Mammalogy 10(4), 340-344. DOI $10.2307 / 1374124$

ERBAJEVA, M.A. 1982. Cenozoic Lagomorphs of Kazakhstan. Materials on the Historical Development of the Fauna and Flora in Kazakhstan, Alma-Ata 8, 25-38.

ERBAJEVA, M.A. 1996. Lagomorphs from Villafranchian sequence in Transbaikalia and their paleoenvironmental implications. Acta zoologica cracoviensia 39(1), 131-135.

ErbajeVA, M.A. \& AleXeEVA, N.V. 2000. Pliocene and Pleistocene biostratigraphic succession of Transbaikalia with emphasis on small mammals. Quaternary International 68-71, 67-75. DOI 10.1016/S1040-6182(00)00033-1

FEJFAR, O. 1961a. Výsledky výzkumu fosilních obratlovců na území ČSSR. Zprávy o geologických výzkumech v roce 1960, 170-172.

FEJFAR, O. 1961b. Review of Quaternary Vertebrata in Czechoslovakia. Institut Geologiczny Warszawa, Prace 34, 108-118.

FEJFAR, O. 1961c. Die plio-pleistozänen Wirbeltierfaunen von Hajnáčka und Ivanovce (Slowakei), ČSR. I. Die Fundumstände und Stratigraphie. Neues Jahrbuch für Geologie und Paläontologie, Abhandlungen 111(3), 257-273.

FEJFAR, O. 1961d. Die plio-pleistozänen Wirbeltierfaunen von Hajnáčka und Ivanovce (Slowakei), ČSSR. III. Lagomorpha. Neues Jahrbuch für Geologie und Palaontologie, Monatshefte $5,267-282$.

FEJFAR, O. 1964a. Výzkum fosilních obratlovců ČSSR v roce 1963. Zprávy o geologických výzkumech v roce 1963, 350-352.

FEJFAR, O. 1964b. The Lower Villafranchian Vertebrates from 
Hajnáčka near Filakovo in Southern Slovakia. Rozpravy Ústředního ústavu geologického 30, 1-115.

FEJFAR, O. \& HEINRICH, W.-D. 1983. Arvicoliden-Sukzession und Biostratigraphie des Oberpliozäns und Quartärs in Europa. Schriftenreihe für geologische Wissenschaften 19/20, 61-109.

FEJFAR, O. \& HEINRICH, W.-D. 1985. Zur Bedeutung der Wirbeltierfundstätten von Ivanovce und Hajnáčka für die Säugetierpaläontologie im Pliozän und frühen Pleistozän in Europa: Kenntnisstand und Probleme. Věstník Ústředního ústavu geologického 60(4), 213-224.

FEJfAR, O., HEINRICH, W.-D. \& HeINTZ, É. 1990. Neues aus dem Villafranchium von Hajnáčka bei Filakov (Slowakei, ČSSR). Quartärpaläontologie 8, 47-70.

FEJFAR, O. \& HORÁČEK, I. 1983. Zur Entwicklung der Kleinsäugerfaunen im Villányium and Alt-Biharium auf dem Gebiet der ČSSR. Schriftenreihe für Geologische Wissenschaften 19/20, 111-207.

FEJFAR, O. \& HORÁČEK, I. 1990. Review of fossil arvicolids (Mammalia, Rodentia) ot the Pliocene and Quaternary in Czechoslovakia, 125-132. In FEJFAR, O. \& HEINRICH, W.-D. (eds) International Symposium Evolution, Phylogeny and Biostratigraphy of Arvicolids (Rodentia,Mammalia). Prague.

FlADERER, F.A. 1984. Das Vordergliedmassenskelett von Hypolagus beremendensis und von Lepus sp. (Lagomorpha, Mammalia) aus dem Altpleistozän von Deutsch-Altenburg (Niederösterreich). Beiträge zur Paläontologie von Österreich 11, 71-74.

FLADERER, F.A. 1987. Beitrag zur Entwicklung von Hypolagus und Lepus (Lagomorpha, Mammalia) im Pliopleistozän von Mitteleuropa. Sitzungsberichte der Österreichischen Akademie der Wissenschaften, Mathematisch-naturwissenschaftliche Klasse, Abteilung I 196, 123-138.

FlADERER, F.A. \& FIORE, M. 2003. The Early Pleistocene insular hare Hypolagus peregrinus sp. nov. from Northern Sicily. Palaeontographia Italica 89, 37-63.

FLADERER, F.A. \& REINER, G. 1996. Evolutionary shifts in the first premolar pattern of Hypolagus beremendensis (Petényi, 1964) (Lagomorpha, Mammalia) in the Plio-Pleistocene of Central Europe. Acta zoologica cracoviensia 39(1), 147-160.

FOSTOWICZ-FRELIK, Ł. 2003. Species distribution and differentiation of Eurasian Hypolagus (Lagomorpha: Leporidae), 197-216. In REUMER, J.W.F. \& WESSELS, W. (eds) Distribution and Migration of Tertiary Mammals in Eurasia. A volume in Honour of Hans de Bruijn. Deinsea 10.

FosTOWICZ-FrELIK, Ł. 2007a. Revision of Hypolagus (Mammalia: Lagomorpha) from the Plio-Pleistocene of Poland: qualitative and quantitative study. Annales Zoologici 57(3), 541-590.

FOSTOWICZ-FrELIK, Ł. 2007b. The hind limb skeleton and cursorial adaptations of the Plio-Pleistocene rabbit Hypolagus beremendensis. Acta Palaeontologica Polonica 52(3), 447-476.

FRANK, C. \& RABEDER, G. 1997. Deutsch-Altenburg, 238-270. In DÖPPES, D. \& RABEDER, G. (eds) Pliozäne und pleistozäne
Faunen Österreichs. Mitteilungen der Kommission für Quartärforschung der Österreichischen Akademie der Wissenschaft, Bd. 10.

GŁAZEK, J., Sulimski, A., SZYNkiewicz, A. \& WysocZAŃSKI-MinKOWICZ, T. 1976. Middle Pleistocene karst deposits with Ursus Speleaus at Draby near Działoszyn, Central Poland. Acta Geologica Polonica 26(3), 451-466.

GŁAZEK, J., Sulimski, A., SZYNKIEWICZ, A. \& WysocZAŃSKI-MINKOWICZ, T. 1977. Kopalny kras ze środkowoplejstoceńskimi kręgowcami w Drabach koło Działoszyna. Kras $i$ Speleologia 1(10), 42-58.

GRADSTEIN, F.M., OGG, J.G. \& KRANENDONK, M. VAN 2008. On the Geologic Time Scale 2008. Newsletters on Stratigraphy 43, 5-13. DOI 10.1127/0078-0421/2008/0043-0005

GUREEV, A.A. 1964. Fauna SSSR, Zaitseobraznye (Lagomorpha), Vol. 3(10). 276 pp. Nauka, Moscow \& Leningrad.

HELlER, F. 1930. Eine Forest-Bed-Fauna aus der Sackdillinger Höhle (Oberpfalz). Neues Jahrbuch für Mineralogie, Geologie und Paläontologie, Abteilung B 63, 247-298.

HELLER, F. 1936. Eine oberpliozäne Wirbeltierfauna aus Rheinhessen. Neues Jahrbuch für Mineralogie, Geologie und Paläontologie, Abteilung B 76, 99-160.

HELLER, F. 1956. Ein kleiner Bär (Ursus sackdillingensis n. sp.) in der cromerischen Fauna der Sackdillinger-Höhle (Oberpfalz). Neues Jahrbuch für Geologie und Paläontologie, Monatshefte 12, 520-530.

HENNIG, W. 1950. Grundzüge einer Theorie der phylogenetischen Systematik. 370 pp. Deutscher Zentralverlag, Berlin.

HiBBARD, C.W. 1963. The origin of the p3 pattern of Sylvilagus, Caprolagus, Oryctolagus and Lepus. Journal of Mammalogy 44(1), 1-15. DOI $10.2307 / 1377162$

HíR, J. \& VenCZEL, M. 1997. New excavation at the locality Betfia IX (Romania, Bihor county). Nymphaea 23-25, 93-116.

HORÁČEK, I. 1979. Výplně 4. sluje na Chlumu u Srbska a jejich význam pro kvartérní stratigrafii (předběžné sdělení). Český kras 4, 19-34.

HORÁČEK, I. 1980. Včeláre 3 - nové naleziště staropleistocénní fauny Slovenského krasu. Slovenský kras 18, 183-192.

HORÁČEK, I. 1982. Výzkum fosilních obratlovců v CHKO Český kras. Památky a př́roda 82(2), 106-111.

HORÁČEK, I. 1984. Mokrá I - nová lokalita staropleistocénní fauny v Moravském krase. Československý kras 34, 55-60.

HORÁČEK, I. 1985. Survey of the fossil vertebrate localities Včeláre 1-7. Časopis pro mineralogii a geologii 30(4), 353-366.

HORÁČEK, I. \& LOŽEK, V. 1984. Z výzkumu výplně Mladečské jeskyně u Litovle. Československý kras 34, 98-100.

HORÁČEK, I. \& LOŽEK, V. 1988. Palaeozoology and the Mid-European Quaternary past: scope of the approach and selected results. Rozpravy ČSAV, Řada matematických a přirodních věd 98, 1-102.

HorÁČEK, I., ČERMÁK, S., WAGNER, J. \& FEJFAR, O. 2006. Měňany 3 - pliocénní fauna obratlovců z Českého krasu. Český kras 32, 32-35.

INTERNATIONAL COMMISSION ON ZOOLOGICAL NOMENCLATURE 
1999. International Code of Zoological Nomenclature. 4th Edition. XXIX + 306 pp. International Trust for Zoological Nomenclature.

JÁNOSSY, D. 1963. Die altpleistozäne Wirbeltierfauna von Kövesvárad bei Répáshuta (Bükk-Gebirge). Annales Historiconaturales Musei nationalis Hungarici, pars Mineralogica et Palaeontologica 55, 109-141.

JÁNOSSY, D. 1972. Ein kleiner Hystrix aus dem Altpleistozin der Fundstelle Osztramos 8 (Nordungarn). Vertebrata Hungarica 13, 163-183.

JÁNOSSY, D. 1973. The boundary of the Plio-Pleistocene based on the Microvertebrates in North Hungary (Osztramos Locality 7). Vertebrata Hungarica 14, 101-113.

JÁNOSSY, D. 1978. Larger Mammals from the Lowermost Pleistocene Fauna, Ostramos, loc. 7 (Hungary). Annales historico-naturales Musei nationalis hungarici 70, 69-79.

JÁNOSSY, D. 1983. Lemming-remain from the Older Pleistocene of Southern Hungary (Villány, Somssich-hegy 2). Fragmenta Mineralogica et Palaeontologica 11, 55-60.

JÁNOSSY, D. 1986. Pleistocene Vertebrate Faunas of Hungary. 208 pp. Akadémiai Kaidó, Budapest.

JÁNOSSY, D. 1987. Ältestpleistozäne vertebratenfauna von Beremend 15 (Sud-Ungarn). Fragmenta Mineralogica et Paleontologica 13, 89-96.

JÁNOSSY, D. 1996. Lower Pleistocene vertebrate faunas from the localities 16 and 17 of Beremend (southern Hungary). Fragmenta Mineralogica et Paleontologica 18, 91-102.

JÁNOSSY, D. \& KORDOS, L. 1977. Az Osztramos gerinces lelóhelyeinek faunisztikai és karsztmorfológiai attekintése (1975-ig). Fragmenta Mineralogica et Paleontologica 8, 39-72.

JÁNOSSY, D. \& KROLOPP, E. 1994. Alsó-pleisztocén Molluscaés gerinces fauna a győrújfalui kavicsbányából. Földtani Közlöny 124/4, 403-440.

JÁNOSSY, D. \& TOPÁL, G. 1990. Allophaiomys-Fauna vom Újlaki-hegy (Budapest). Annales historico-naturales Musei nationalis hungarici 81, 17-26.

KoBY, F.-E. 1960. Contribution à la connaissance des livères fossiles, principalelement de ceux de la dernière glaciation. Verhandlungen der Naturforschenden Gesellschaft. Basel 71(1), 149-173.

KoCH, A. 1900. A Magyar Korona országai kövült gerincesállat maradványainak rendszeres átnézete. A Magyar Orvosok és Természetvizsgálók. Vándorgyülésének történeti vázlata és Munkálatai 30, 526-560.

KoEnigswald, W. vON \& HeInRICH, W.-D. 1999. Mittelpleistozäne Säugetierfaunen aus Mitteleuropa - der Versuch einer biostratigraphischen Zuordnung. Kaupia - Darmstädter Beiträge zur Naturgeschichte 9, 53-112.

KoRDOS, L. 1991. Upper Pliocene paleovertebrate localities, Beremend, Villány Mts. Magyarország geológiai alapszevényei 1991, 1-6.

Kormos, T. 1911. Canis (Cerdocyon) petényii n. sp. und anderer interessante Funde aus dem Komitat Baranya. Jahrbuch der Königlich Ungarischen Geologischen Anstalt 19(4), 167-196.

KoRMOS, T. 1914a. Die phylogenetische und zoogeographische
Bedeutung präglazialer Faunen. Verhandlungen der Zoologisch-botanischen Gesellschaft 1914, 218-238.

KoRMOS, T. 1914b. Az 1913. évben végzett ásatásaim eredményei (Über die Resultate meiner Ausgrabungen im Jahr 1913). A Magyar Állami Földtani Intézet Évi Jelentése az 1913; (Jahresbericht der königlich ungarischen Geologischen Reichsanstalt für 1913) 498-540 (in Hungarian); 559-604 (in German).

KoRMOS, T. 1920. Die präglazialen Bildungen des Villányer Gebirges und ihre Fauna. Jahresbericht der königlich ungarischen Geologischen Reichsanstalt 1916, 448-466.

KORMOS, T. 1930. Új adatok a püspökfürdői Somlyóhegy preglaciális faunájához (Beiträge zur Präglazialfauna des Somlyoberges bei Püspökfürdő). Állattani Közlemények 27(1-2), 40-62.

KoRMOS, T. 1930 [1931]. Diagnosen neuer Säugetiere aus den oberpliozänen Fauna des Somlyöberges, Püspökfürdö. Annales Musei Nationalis Hungarici 27, 237-246.

KoRMOS, T. 1934. Az eurázsiai nyulak származástani problémája (Zur Frage der Abstammung eurasiatischer Hasen). Állattani Közlemények 31(1-2), 65-78.

KoRMOS, T. 1937a. Zur Geschichte und Geologie der oberpliozänen Knochenbreccien des Villányer Gebirges. Mathematischer und Naturwissenschaftlicher Anzeiger der ungarischen Akademie der Wissenschaften 56, 1063-1100.

KoRMOS, T. 1937b. Zur Frage der Abstammung und Herkunft der quartären Säugetier-Fauna Europas. Festschrift zum 60. Geburstage von Prof. Dr. Embrik Strand 3, 287-328.

Koufos, G.D., Kostopoulos, D.S. \& Vlachou, T.D. 2005. Neogene/Quaternary mammalian migrations in Eastern Mediterranean. Belgian Journal of Zoology 135(2), 181-190.

KOWALSKI, K. 1958a. An early Pleistocene fauna of small mammals from the Kadzielnia Hill in Kielce (Poland). Acta Palaeontologica Polonica 3, 1-47.

KowALSKI, K. 1958b. Altpleistozäne Kleinsäugerfauna von Podumica im Norddalmatien. Palaeontologia Jugoslavica 2, 1-30.

KowALSKI, K. 1961. Fauna pliocénska z Wężów koło Działoszyna. Wszechświat 7-8(1923), 157-161.

KowALSKI, K. 1964. Paleoekologia ssaków pliocenu i wczesnego plejstocenu Polski. Acta Theriologica 8(4), 73-88.

KOWALSKI, K. 1974. The vertebrate fauna of the Upper Pliocene and Villafranchian in Poland. Mémoires du Bureau de Recherches Gèologiques et Minères 1(78), 197-202.

KOWALSKI, K. 1975. Earliest appearance of lemmings in the Quaternary of Poland. Trabajos Sobre Neogene-Cuaternario 4, 99-104.

KowAlsKI, K. 1977. Mammalia, 97-100. In CZERMInSKI, J. (ed.) Geology of Poland, Volume II, Catalogue of fossils, Part 3 a Cainozoic. Publishing House Wydawnictwa Geologiczne, Warsaw.

KRETZOI, M. 1938. Die Raubtiere von Gombaszög nebst einer Übersicht der Gesamtfauna (Ein Beitrag zur Stratigraphie des Altquartärs). Annales Musei Nationalis Hungarici pars mineralogica, geologica, paleontologica 31, 88-157.

KretzoI, M. 1941a. Weitere Beiträge zur Kenntnis der Fauna 
von Gombaszög. Annales Musei Nationalis Hungarici pars mineralogica, geologica, paleontologica 34, 105-139.

KretzoI, M. 1941b. Ősemlősmaradványok Bétfiáról (Die unterpleistozäne Säugetierfauna von Betfia bei Nagyvárad). Földtani Közlöny 71, 235-261 (in Hungarian); 308-335 (in German).

KRETZOI, M. 1954. Bericht über die calabrische (villafranchische) Fauna von Kislang, Kom. Fejér. Állami Földtani Intézet Évijjelentése az 1953(1), 239-265.

KretzoI, M. 1955. Promimomys cor n. g. n. sp., ein altertümlicher Arvicolide aus dem ungarischen Unterpleistozän. Acta Geologica Academiae Scientiarum Hungaricae 3(1-3), 89-94.

KRETZOI, M. 1956a. Újabb gyújtések a Villányi-hegység gerinces-lelőhelyein. A Magyar Állami Földtani Intézet Évijjelentése az 1954, 81-91.

KRETZOI, M. 1956b. Die altpleistozänen Wirbeltierfaunen des Villányer Gebirges. Geologica Hungarica, Series Palaeontologica 27, 1-264.

KRETZOI, M. 1962. Fauna und Faunenhorizont von Csarnóta. A Magyar Állami Földtani Intézet Évi Jelentése az 1959, 344-395.

KRETZOI, M. 1965. Die Nager und Lagomorphen von Voigtstedt in Thüringen und ihre chronologische Aussage. Paläontologische Abhandlungen 2(3), 587-660.

KUBINYI, F. 1856. Emlősök és hüllők maradványai a beremendi csonttorlatban. Eggenberger Ferdinánd M. Academiai Könyvárusnál 1856, 69-77.

LOŽEK, V. 1964. Quartärmollusken der Tschechoslowakei. Rozpravy Ústředního ústavu geologického 31, 1-374.

LOŽEK, V. \& HORÁČEK, I. 1992. Slovenský kras ve světle kvartérní geologie. Slovenský kras 30, 29-56.

MAIS, K. \& RABEDER, G. 1977a. Eine pliozäne Höhlenfüllung im Pfaffenberg bei Bad Deutsch-Altenburg (Niederösterreich). Die Höhle 28(1), 1-7.

MAIS, K. \& RABEDER, G. 1977b. Eine weitere plio-pleistozäne Höhlenfauna aus dem Steinbruch Hollitzer bei Bad DeutschAltenburg (Niederösterreich). Die Höhle 28(3), 84-86.

MALEZ, M. 1959. A new Old-Pleistocene Fauna in Dalmatien. Bulletin Scientifique 5(1), 13-14.

MALEZ, M. 1960. Etruskisches Nashorn - Dicerorhinus etruscus (Falconer) - aus altpleistozänen Brekzien der Halbinsel Marjan bei Split (Dalmatien). Anthropos, Supplement 1960 (Mammalia pleistocaenica I), 115-123.

MALEZ, M. 1961. Staropleistocenska fauna koštane breče poluotoka Marjana kod Splita. Palaeontologia Jugoslavica 4, 1-43.

MALEZ, M. 1962. Paleontološka istraživanja i speleološka rekognosciranja u 1959 godini. Ljetopis Jugoslavenske Akademije Znanosti i Umjetnosti 66, 309-324.

MALEZ, M. 1968a. Die altpleistozänische Vertebratenfauna in dem Gebiete des Dinarischen Karstes. Bulletin Scientifique, Section A 13(5/6), 152.

MALEZ, M. 1968b. O razvoju kvartara na području Vanjskih Dinarida. Prvi Kolokvij o geologiji Dinaridov 1, 203-210.

MALEZ, M. 1969a. Donjopleistocenske faune vertebrata na području Dinarskog krša. III Simpozij Dinarske Asocijacie, 73-80.
MALEZ, M. 1969b. Die altpleistozänen Wirbeltierfaunen aus den Höhlen von Kroatien. Proceedings of the $5^{\text {th }}$ International Congress of Spelology 1969(4), B 21/1-B 21/6.

MALEZ, M. 1970. Pećinska nalazišta donjopleistocenskih fauna na području Dinarskog krša. Congrès Yugoslave de spéléologie, cinquème session, 205-214.

MALEZ, M. 1971. Naseljavanje Dinarskog krša u pleistocenu. Simpozij o zaštiti prirode u našem kršs, 63-80.

MALEZ, M. \& RABEDER, G. 1984. Neues Fundmaterial von Kleinsäugern aus der altpleistozänen Spaltfüllung Podumci 1 in Norddalmatien (Kroatien, Jugoslawien). Beiträge zur Paläontologie von Österreich 11, 439-510.

Matthee, C.A., Van Vuuren, B.J., Bell, D. \& Robinson, T.J. 2004. A molecular supermatrix of the rabbits and hares (Leporidae) allows for the identification of five intercontinental exchanges during the Miocene. Systematic Biology 53, 433-447. DOI 10.1080/10635150490445715

MAUL, L. 1990. Überblick über die unterpleistozänen Kleinsäugerfaunen Europas. Quartärpaläontologie 8, 153-191.

MAUL, L. 1998. A provisional distribution history of the Lagomorpha in Europe during the Pleistocene and the Late Pliocene, 122. In REIG, S. (ed.) Euro-American Mammal Congress, Abstract volume. Universidad de Santiago de Compostella, Santiago de Compostella.

MAUL, L. 2007. Erster Nachweis von Hypolagus (Leporidae, Mammalia) in der unterpleistozänen Fundstelle Untermaßfeld (Thüringen, Mitteldeutschland). Beiträge zur Geologie von Thüringen, Neue Folge 14, 215-233.

Maul, L.C., Heinrich, W.-D., ParfitT, S.A. \& Paunescu, A.-C. 2007. Comment on the correlation between magnetostratigraphy and the evolution of Microtus (Arvicolidae, Rodentia, Mammalia) during the Early and early Middle Pleistocene. Courier Forschungs-Institut Senckenberg 259, 243-263.

MCKENNA, M.C. \& BELL, S.K. 1997. Classification of mammals above the species level. 631 pp. Columbia University Press, New York.

MEYER, H. VON 1851. Mittheilungen an Professor Bronn gerichtet. Neues Jahrbuch für Mineralogie, Geognosie, Geologie und Petrefakten-Kunde 1851, 677-680.

MossocZY, Z. 1959. Odkrycie miejsc występowania kości kręgowców kopalnych w okolicach Kłobucka. Przeglad Geologiczny 3, 132-134.

Musil, R. 1965. Aus der Geschichte der Stránská skála. Acta Musei Moraviae 50, 75-106.

MusIL, R. 1966. Holštejn, eine neue altpleistozänen Lokalität in Mähren. Acta Musei Moraviae 51, 133-168.

MusIL, R. 1968. Neue Ergebnisse der Forschungen an der Lokalität Stránská skála. Acta Musei Moraviae 53, 139-162.

MusIL, R. 1974. Lažánky bei Tišnov - eine neue Fundstätte der Biharfauna. Acta Musei Moraviae 59, 87-93.

MUSIL, R. 2001. Zur biostratigrafischen Gliederung des Quartärs in Mähren (Tschechische Republik), 27-38. In WAGNER, G.A. \& MANIA, D. (eds) Frühe Menschen in Mitteleuropa Chronologie, Kultur, Umwelt. Aachen.

Musil, R., KARÁSEK, J., NeHYBA, S., PElíšEK, J., SMOlÍKOVÁ, 
L., KahlKe, H.-D., IVAnOV, M., MlíKovskÝ, J., Kovanda, J., SVObodová, H., PŘichystal, A., StRnAD, M., VAlOCH, R. \& PATOU-MATHIS, M. 1995. Stránská skála Hill. Excavation of open-air sediments 1964-1972. Anthropos 26(18), 1-213.

Musil, R. \& VALOCH, K. 1968. Stránská skála: its meaning for pleistocene Studies. Current Antropology 9(5), 534-539. DOI $10.1086 / 200950$

MUSIL, R. \& VALOCH, K. 2005. Environmental changes spanning the Early-Middle Pleistocene transition. Jahresschrift für mitteldeutsche Vorgeschichte 89, 51-98.

OGG, J.G. \& PILLANS, P. 2008: Establishing the Quaternary as a formal international period/system. Episodes 31, 230-233.

PAlacios, F. \& LÓPEZ-MARTíneZ, N. 1980. Morfología dentaria de las liebres europeas (Lagomorpha, Leporidae). Doñana Acta Vertebrata 7(1), 61-81.

PALMER, T.S. 1904. Index Generum Mammalium: a list of the genera and families of mammals. 984 pp. North American Fauna, No. 23. U.S. Department of Agriculture, Washington.

PAUNOVIC, M. \& RABDER, G. 1996. Die altpleistozänen Kleinsäugerfaunen Razvodje und Tatinja draga in Süd-Kroatien. Beiträge zur Paläontologie 21, 69-84.

PETÉNYI, S.J. 1864. A beremendi mészkőbánya természetrajz-és őslénytanilag Petényi Salamon által leírva, 35-81. In KUBINYI, F. (ed.) Petényi S. János Hátrahagyott munkái. Magyar Tudományos Akademia, Pest.

PICTET, F.J. 1853. Traite de paleontologie, ou, Histoire naturelle des animaux fossiles consideres dans leurs rapports zoologiques et geologiques. Vol. 1. 584 pp. J.B. Baillère, Paris.

PoPOV, V.V. 1988. Middle Pleistocene small mammals (Mammalia: Insectivora, Lagomorpha, Rodentia) from Varbeshnitsa (Bulgaria). Acta zoologica cracoviensia 31(5), 193-234.

POPOV, V.V. 2004. Pliocene small mammals (Mammalia, Lipotyphla, Chiroptera, Lagomorpha, Rodentia) from Muselievo (North Bulgaria). Geodiversitas 26(3), 403-491.

QIU, Z. 1987. The Neogene mammalian faunas of Ertemte and Harr Obo in Inner Mongolia (Nei Mongol), China. 6: Hares and pikas - Lagomorpha. Leporidae and Ochotonidae. Senckenbergiana lethaea 67, 375-399.

RABEDER, G. 1983. Neues von Höhlenbären. Zur Morphogenetik der Backenzähne. Die Höhle 34(2), 67-85.

RABEDER, G. \& TsoukalA, E. 1990. Morphodynamic analysis of some cave-bear teeth from Petralona cave (Chalkidiki, North-Greece). Beiträge zur Paläontologie von Österreich 16, 103-109.

RADULESCO, C. \& SAMSON, P. 1967. Contribution à la connaissance du complexe faunistique de Malusteni-Beresti (Pléistocène inférieur), Roumanie I. Ord. Lagomorpha, Fam. Leporidae. Neues Jahrbuch für Geologie und Paläontologie, Monatshefte 9, 544-563.

RADULESCO, C. \& SAMSON, P. 1985. Pliocene and Pleistocene mammalian biostratigraphy in southeastern Transylvania (Romania). Travaux de l'Institut de Speologie "Emile Racovitza" $24,85-95$.

RAdulesco, C. \& SAMSON, P. 1986. Les mammifères du Pléistocène inférieur d'Izvoru (Département d'Olt, Roumanie). Quartärpaläontologie 6, 157-171.
Radulesco, C. \& SAMSOn, P. 1990. The Plio-Pleistocene Mammalian Succession of the Oltet Valley, Dacic Basin, Romania. Quartärpaläontologie 8, 225-232.

RADULESCO, C. \& SAMSON, P. 2001. Biochronology and evolution of the Early Pliocene to the Early Pleistocene mammalian faunas of Romania. Bollettino della Società Paleontologica Italiana 40(2), 285-291.

Rössner, G. \& HeISSIG, K. (eds) 1999. The Miocene Land Mammals of Europe. 516 pp. Dr. Friedrich Pfeil Verlag, Munich.

SABOL, M. 2001. Villafranchian Locality Hajnáčka I: Comparison of older data with new ones. Slovak Geological Magazine 7(3), 275-287.

SABOL, M. 2003. New findings of Late Pliocene vertebrates from Hajnáčka I site (southern Slovakia). Coloquios de Paleontología, Vol. Ext. 1(2003), 595-602.

SABOL, M. (ed.) 2004. Early Villanyian site of Hajnáčka I (Southern Slovakia). Paleontological research 1996-2000. 144 pp. Gemer-Malohont Museum in Rimavská Sobota.

SABOL, M., ĎurišovÁ, A., HoleC, P. \& JANŠTovÁ, M. 2005. Pliocénna tafocenóza z lokality Hajnáčka I, 7-18. In BoDOROVÁ, O. (ed.) Gemer-Malohont I. 2005. Zborník Gemersko-malohontského múzea v Rimavskej Sobote. Rimavská Sobota.

SAbol, M., JoniaK, P. \& Holec, P. 2004. Succesion(-s) of mammalian assemeblages during the Neogene - a case study from the Slovak part of the Western Carpathians. Scripta Facultatis Scientiarum Naturalium Universitatis Masarykianae Brunensis, Geology 31-32 (2001-2002), 65-84.

SABOL, M., KONEČNÝ, V., VASS, D., KovÁČOVÁ, M., ĎURIŠOVÁ, A. \& TÚNYI, I. 2006. Early late Pliocene site of Hajnáčka 1 (Southern Slovakia) - geology, palaeovolcanic evolution, fossil assemblages and palaeoenvironment. Courier Forschungsinstitut Senckenberg 256, 261-274.

SCHREUDER, A. 1937. Hypolagus from the Tegelen clay; with a note on recent Nesolagus. Archives Neérlandaises de Zoologie 2(2/3), 225-239.

SHUSHPANOV, K.I. 1977. Ostatki zaitsev (rody Pliolagus i Lepus) iz verkhnego pliocena yuga Moldavii i Ukrainy. Izvestia Akademii Nauk Moldavskoi SSR 6, 59-63.

Simpson, G.G. 1961. Principles of Animal Taxonomy. 247 pp. Columbia University Press, New York.

ŠUF, J. 1931. Diluviální zvířena od Gombaseku u Rožňavy na Slovensku. Věstník Státního geologického ústavu Československé republiky 7, 161-172.

SULIMSKI, A. 1962. O nowym znalezisku kopalnej fauny kregowców w okolicy Działoszyna. Przeglad Geologiczny 10, 219-223.

SULIMSKI, A. 1964. Pliocene Lagomorpha and Rodentia from Węże 1 (Poland). Acta Paleontologica Polonica 9(2), 149-262.

SYCH, L. 1964. Fossil Laporidae from the Pliocene and Pleistocene of Poland, 591-594. In DYLIK, J. (ed.) Report of the $4^{\text {th }}$ International Congress on Quaternary in Warsawa 1961. Łódź.

SYCH, L. 1965. Fossil Leporidae from the Pliocene and the Pleistocene of Poland. Acta zoologica cracoviensia 10(1), 1-88. 
SYCH, L. 1966. Correlation of tooth measurements in leporids. On the significance of the coefficient of correlation in the studies of microevolution. Acta Theriologica 11, 41-54.

SYCH, L. 1967a. Unworn teeth of Hypolagus brachygnathus Kormos (Leporidae, Mammalia). Acta zoologica cracoviensia 12(2), 19-26.

SYCH, L. 1967b. Fossil Endocranial Cast of Hypolagus brachygnathus Kormos (Leporidae, Mammalia). Acta zoologica cracoviensia 12(3), 27-30.

SYCH, L. 1980. Lagomorpha (Mammalia) from the Pliocene and Early Pleistocene of Poland. Folia Quaternaria 51, 57-64.

TASNÁDI-KubaCSKA, A. \& Soós, L. 1935. Die Mollusken- und Wirbeltierfauna des Plistozän und Ober-Pliozän von Gombaszög. Annales Musei Nationalis Hungarici pars mineralogica, geologica, paleontologica 29, 9-20.

TEILHARD DE ChARDIN, P. 1940. The fossils from Locality 18 near Peking. Palaeontologica Sinica, New Series C 9, $1-101$.

TERZEA, E. 1973. A propos d'une faune villafranchienne finale de Betfia (Bihor, Roumanie). Travaux de l'Institut de Spéologie "Emile Racovitza" 12, 229-242.

TerZEA, E. 1996. Biochronology of the Pleistocene deposits at Betfia (Bihor, Romania). Acta zoologica cracoviensia 39(1), 534-540.

TERZEA, E. \& JURCSÁK, T. 1969. Contributii la cunoasterea faunelor pleistocene mediide la Betfia (Romania). Travaux de l'Institut de Spéologie "Emile Racovitza" 8, 201-214.

TERZEA, E. \& JuRCSÁK, T. 1976. Faune de Mammiferes de Betfia-XIII (Bihor, Roumania) et son âge géologique. Travaux de l'Institut de Spéologie "Emile Racovitza” 15, 175-185.

THENIUS, E. 1948. Fischotter und Bisamspitzmaus aus dem Altquartär von Hundsheim in Niederösterreich Sitz. Sitzungsberichte der österreichischen Akademie der Wissenschaften in
Wien, Mathematisch-naturwissenschaftiche Klasse 157, 187-202.

TOBIEN, H. 1972. Citellus (Rodentia) und Lagomorpha aus den älteren Aufsammlungen an der pleistozänen Lokalität Stránská skála bei Brno (ČSSR). Anthropos 20(12), 137-146.

TOBIEN, H. 1974. Villafranchian Mammals in Western Germany. Mémoires du Bureau de Recherches Gèologiques et Minères 1(78), 259-265.

TOBIEN, H. 1980. Säugerfaunen von der Grenze Pliozän/Pleistozän in Rheinhessen. 1. Die Spaltfüllungen von Gundersheim bei Worms. Mainzer geowissenschaftliche Mitteilungen 8, 209-218.

VOORHIES, M.R. \& TIMPERLEY, C.L. 1997. A new Pronotolagus (Lagomorpha: Leporidae) and other leporids from the Valentine Railway Quarries (Barstovian, Nebraska), and the Archaeolaginae-Leporinae transition. Journal of Vertebrate Paleontology 17(4), 725-737.

WhITE, J.A. 1991. North American Leporinae (Mammalia: Lagomorpha) from Late Miocene (Clarendonian) to latest Pliocene (Blancan). Journal of Vertebrate Paleontology 11(1), $67-89$.

WhITE, J.A. \& MORGAN, N.H. 1995. The Leporidae (Mammalia: Lagomorpha) from the Blancan (Pliocene) Taunton Local fauna of Washington. Journal of Vertebrate Paleontology 15(2), 366-374.

WoLSAN, M. 1989. Zajęczaki, Lagomorpha, 145-150. In KoWALSKI, K. (ed.) Historia i ewolucja ladowej fauny Polski. Folia Quaternaria 59-60. Kraków.

Wolsan, M. 1990. Lower Pleistocene lagomorphs of Poland. Quartärpaläontologie 8, 273-276.

ŽÁK, K. \& DIEDRICH, C.G. 2006. Sedimenty krasových výplní v lomu Plešivec u Měňan - předběžná zpráva o výzkumu. Český kras 32(2006), 26-31. 